University of Louisville

ThinkIR: The University of Louisville's Institutional Repository

$5-2013$

\title{
Assessing the role of transnational networks of support in color revolutions : successes and failures in Georgia, Ukraine, Belarus, and Russia.
}

Michael C. Zeller

University of Louisville

Follow this and additional works at: https://ir.library.louisville.edu/honors

Part of the Political Science Commons

\section{Recommended Citation}

Zeller, Michael C., "Assessing the role of transnational networks of support in color revolutions : successes and failures in Georgia, Ukraine, Belarus, and Russia." (2013). College of Arts \& Sciences Senior Honors Theses. Paper 27.

http://doi.org/10.18297/honors/27

This Senior Honors Thesis is brought to you for free and open access by the College of Arts \& Sciences at ThinkIR: The University of Louisville's Institutional Repository. It has been accepted for inclusion in College of Arts \& Sciences Senior Honors Theses by an authorized administrator of ThinkIR: The University of Louisville's Institutional Repository. This title appears here courtesy of the author, who has retained all other copyrights. For more information, please contact thinkir@louisville.edu. 


\section{Assessing the Role of Transnational Networks of Support in Color Revolutions: Successes and Failures in Georgia, Ukraine, Belarus, and Russia}

Michael C. Zeller, University of Louisville

It is not important who votes or how, but it is extraordinarily important who counts the votes. - Josef Stalin (attributed by his secretary, Boris Bazhanov) ${ }^{1}$

In the second decade after the disintegration of the Soviet Union, a sociopolitical phenomenon developed in several post-Soviet states: color revolution movements. Political and societal opposition, spurred by electoral fraud perpetrated by (semi-) authoritarian governments, sought the restoration of their legitimate voting prerogatives and often the accompanying ouster of the prevailing political regime.

The phrase "color revolution" typically applies to a series of democratic movements produced in part by electoral fraud; while the term originally referred to movements in the former Soviet Union that first appeared in the early 2000s, democratic and anti-authoritarian movements in Asia and the Middle East have since been labeled "color revolutions." Nonviolent resistance, a discernable international element, and student and youth activism number among the prominent characteristics of these movements. A robust and assertive civil society represents perhaps the most outstanding feature present in color revolutions. In these instances, civil society is appropriately understood by the definition provided by Alfred Stepan and Juan Linz: "that arena of the polity where self-organizing and relatively autonomous groups, movements, and individuals attempt to articulate values, to create associations and solidarities, and to advance their interests."2

\footnotetext{
${ }^{1}$ Bazhanov, Boris. Vospominaniya byvshchevo sekretarya Stalina. Parizh: Tretya Bolna, 1980. Quote translated by author: “я считаю, что совершенно неважно, кто и как будет в партии голосовать; но вот что чрезвычайно важно, это - кто и как будет считать голоса."

${ }^{2}$ Linz, Juan J., and Alfred Stepan. "Toward Consolidated Democracies." Journal of Democracy 7, no. 2 (1996): 15.
} 
This paper seeks to identify transnational democratic networks that countered (semi-)

authoritarian regimes in the form of color revolution movements, to examine how regimes have responded to this existential threat, and to evaluate the importance of this dynamic in determining the success or failure of color revolutions.

\section{Theory Pertaining to Transnational Networks of Support and Color Revolutions}

The phenomena of color revolutions sparked considerable academic inquisition into the commonalities of the movements. What preconditions and procedural developments characterize a color revolution? Examining movements in Serbia, Georgia, and Ukraine in the early 2000s, Michael McFaul concludes that successful color revolutions shared at least seven factors:

1) a semi-autocratic rather than fully autocratic regime; 2) an unpopular incumbent; 3) a united and organized opposition; 4) an ability to quickly drive home the point that voting results were falsified, 5) enough independent media to inform citizens about the falsified vote, 6) a political opposition capable of mobilizing tens of thousands or more demonstrators to protest electoral fraud, and 7) divisions among the regime's coercive forces. ${ }^{3}$

Factors four through six, however, implicate an un-enumerated factor: transnational networks of support. Furthermore, the popularity of an incumbent executive as well as opposition unity may be the result of network influence.

The organization and effectiveness of political opposition and the dispersion of alternative sources of information (to those of the government) frequently depends on the influence of domestic and international elements operating within the country. The intercession in political affairs, either directly or indirectly, of foreign agencies and organizations can activate or enhance heretofore dormant or underdeveloped nodes of political activity. Indeed, some non-

\footnotetext{
${ }^{3}$ McFaul, Michael. “Transitions from Postcommunism.” Journal of Democracy 16, no. 3 (2005): 7.
} 
domestic actors interact with dynamic societal components and endeavor to foster a political culture antithetical to the prevailing degree of autocracy in the governing regime.

The influence of these "transnational advocacy networks," is presently undervalued and generally misunderstood, according to scholars Margaret Keck and Kathryn Sikkink. ${ }^{4}$ They define such networks as including "those actors working internationally on an issue, who are bound together by shared values, a common discourse, and dense exchanges of information and of services." ${ }^{\circ}$ That is, groups with common goals and similar temperaments (irrespective of nationality) sometimes coalesce into interconnected associations for the purpose of maximizing resources and efficacy. Within these value-oriented nexuses major actors "may include the following: (1) international and domestic NGOs, research and advocacy organizations; (2) local social movements; (3) foundations; (4) the media; (5) churches, trade unions, consumer organizations, intellectuals; (6) parts of regional and international intergovernmental organizations; (7) parts of the executive and/or parliamentary branches of governments."6

Transnational advocacy networks frequently develop out of claims of rights violations, necessarily involving some government(s).

Governments are the primary 'guarantors' of rights, but also among their primary violators. When a government violates or refuses to recognize rights, individuals and domestic groups often have no recourse within domestic political or judicial arenas. They may seek international connections to express their concerns and even to protect their lives. ${ }^{7}$

Keck and Sikkink call this search for international support so as to aggregate and exert greater pressure on a state "the boomerang pattern." The enlistment of outside support multiplies the

\footnotetext{
${ }^{4}$ Keck, Margaret E., and Kathryn Sikkink. Activists Beyond Borders: Advocacy Networks in International Politics. Ithica: Cornell University Press, 1998.

${ }^{5}$ Keck, Margaret E., and Kathryn Sikkink. "Transnational advocacy networks in international and regional politics." International Social Science Journal 51, no. 159 (1999): 89.

${ }^{6}$ Ibid: $91-92$.

${ }^{7}$ Ibid: 93 .
} 
force of a domestic actor's (actors') effect and impairs the ability of disinclined governments to ignore or repress the issue being presented. Relationships and collaboration among the various network constituents quickly becomes elaborate. The interaction, according to Keck and Sikkink, is dynamic; exchanges of funds and other resources, services, and information occur frequently inside "a dense web of connections among these groups, both formal and informal." Thus, suppression of a network not only becomes less acceptable because of the international elements, but also less practical due to the sheer intricacy of the system.

Yet the context of regime change as a result (at least partially) of transnational political network activity demands a definite understanding of the nationality dimension. That is, network resources tend to flow into a given country rather than even or inverse resource movement between domestic and international network constituents. Cursory examination of this relationship pattern might imply a dependency of domestic actors upon their foreign beneficiaries, that revolutions via such networks are steered by international elements through their domestic consumers. Rather, the aspects of clientelism typically predominate the early stages of network relations. It fades quickly and virtually disappears by the time domestic network actors are prepared to challenge an authoritarian system. "With rare exception, domestic actors dominate the drama of regime change; external actors can influence outcomes only by working with and through these domestic actors."

In the cases of color revolutions, it is appropriate to examine some of the larger NGOs and state actors that promote healthy civil society and other conditions of democracy, which might constitute the major international elements of a network seeking democratic reform or revolution. Valerie Bunce and Sharon Wolchik report that agencies and non-governmental

\footnotetext{
${ }^{8}$ Ibid: 92.

${ }^{9}$ McFaul, Michael. "Ukraine Imports Democracy." International Security 32, no. 2 (2007): 47.
} 
organizations (NGOs) like the U.S. Agency for International Development (USAID), the National Endowment for Democracy, the Open Society Institute, the Organization for Security and Cooperation in Europe (OSCE), and the European Union have deployed considerable resources to the post-Soviet space. These entities count democratic promotion among their core objectives. Indeed, each of their mission statements reflect this fact:

- USAID: "Create a more secure, democratic, and prosperous world for the benefit of the American people and the international community." 10

- National Endowment for Democracy: "...dedicated to the growth and strengthening of democratic institutions around the world."11

- Open Society Institute: “The Open Society Foundations work to build vibrant and tolerant societies whose governments are accountable and open to the participation of all people." 12

- OSCE: "...promoting the full respect of human rights and fundamental freedoms."13

- European Union (through EuropeAid): "European Union believes that democracy and human rights are universal values that should be vigorously promoted around the world." 14

Of the resources that these organizations have committed to the post-Soviet space, Bunce and Wolchik demonstrate that the preponderance has been focused "on elections and political-party development," 15 that is, building blocks of stable democratic systems. The democracy assistance and promotion of these entities has met with success most in states that: "1) have kept one foot in the democratic door, perhaps by holding regular and at least somewhat competitive elections; 2) have parties and a developed civil society that can act as local allies for democratization efforts;

\footnotetext{
10 "Mission Statement of the U.S. Department of State and USAID." U.S. Department of State. http://www.state.gov/s/d/rm/rls/dosstrat/2004/23503.htm. [Author's italics]

11 "About the National Endowment for Democracy." National Endowment for Democracy. http://www.ned.org/about

12 “About Us | Open Society Foundations (OSF).” Open Society Foundations (OSF). http://www.opensocietyfoundations.org/about

13 "What we do." Organization for Security and Co-operation in Europe | OSCE. http://www.osce.org/what

14 "Development and Cooperation - EuropeAid." European Commission. ec.europa.eu/europeaid/what/humanrights/index_en.htm

${ }^{15}$ Bunce, Vălerie J., and Sharon L. Wolchik. "Favorable Conditions and Electoral Revolutions." Journal of Democracy 17, no. 4 (2006): 13.
} 
3) exhibit short-term democratization-friendly trends such as increasingly competitive local elections, popular protests, vigorous legislatures and courts, cooperation among opposition groups, and popular opposition leaders; and 4) share borders with states that are both democratic and similar to them." 16

To be sure, one of the more significant elements of transnational advocacy networks in fomenting color revolution movements is the experience of previous movements and the diffusion of tactics across borders. The success of the Otpur movement (a youth activist group) in Serbia in the 2000 Bulldozer revolution, for instance, led to the exportation of that model youth advocacy under the principles of non-violent resistance and mass citizen mobilization - to neighboring countries: Georgia's Kmara movement played an integral role in the Rose Revolution, Pora in Ukraine's Orange Revolution, and Zubr in Belarus. Several methods of transnational political networks have dispersed in similar ways, by the movement of experienced domestic or international actors to burgeoning democratic movements in other authoritarian or semi-authoritarian states.

Diffusion is not limited to the democratic opposition networks, however. The experience of strongmen leaders in early color revolutions served as a warning to other regional authoritarians. Harassment or outright expulsion of (perceived) opposition organizations or agencies, creation of counter-revolutionary political groups and networks, and limits on electoral competition and process observation number among the techniques developed in some countries of the former Soviet Union to bolster undemocratic regimes. This response is understood in light of the fact that "although most external democracy activists may indeed be primarily interested

\footnotetext{
${ }^{16}$ Ibid: 14.
} 
in achieving free and fair elections, they also frequently hope that their efforts will increase the likelihood that autocrats will lose office."17

Evgeny Finkel and Yitzhak Brudny identify five major strategies of authoritarian incumbents in their attempts to tactically, institutionally, and culturally preempt color revolution movements: "isolation, marginalization, distribution, repression, and persuasion." ${ }^{18}$ By meting out subsidiary variations of these broad strategies, authoritarian regimes restrain societal and foreign elements that previously generated color revolutions in neighboring countries. "This growing backlash has yet to coalesce into a formal or organized movement. But its proponents are clearly learning from and feeding off one another." 19

Some scholars ${ }^{20}$ hold that robust transnational advocacy networks (with dependable support from external constituents like USAID) precipitated regime change even in countries that did not possess all the conditions explicated by analysts like Michael McFaul. If so, what can the experience of democratic movements in the post-Soviet space reveal about the function of transnational networks of support in color revolutions? What forms of international support were present in the recent democratic movements in Georgia (2003-04), Ukraine (2004-05), Belarus (2006), and Russia (2011-12); what was the extent of that support? What accounts for the success or failure of color revolutions in Georgia, Ukraine, Belarus, and Russia to achieve regime change? How did international networks of support - and the challenged government's approach to those elements - factor in the success or failure of these color revolution movements?

\footnotetext{
${ }^{17}$ Carothers, Thomas. "The Backlash against Democracy Promotion.” Foreign Affairs 85, no. 2 (2006): 61 - 62.

${ }^{18}$ Finkel, Evgeny, and Yitzhak Brundy. "No More Colour! Authoritarian Regimes and Colour Revolutions in Eurasia." Democratization 19, no. 1 (2012): 6.

${ }^{19}$ Carothers, "The Backlash against Democracy Promotion": 55.

${ }^{20}$ See especially: Beissinger, Mark R.. "Structure and Example in Modular Political Phenomena: The Diffusion of Bulldozer/Rose/Orange/Tulip Revolutions.” Perspectives on Politics 5, no. 2 (2007): 259 - 276. http://www.jstor.org/stable/20446423.
} 


\section{Methodology}

The paper investigates four cases of democratic movements in the post-Soviet space Georgia, Ukraine, Belarus, Russia - from a comparativist perspective, identifying similarities and differences in the activities of transnational networks of support in order to assess their role in the success or failure of the movement. The examination of transnational network activity within two successful color revolution movements (Georgia and Ukraine) and two failed movements (Belarus and Russia) allows for an authoritative cross-referencing of causal factors. Using Charles Ragin's method of "Qualitative Comparative Analysis," ${ }^{21}$ which employs Boolean algebra and John Stuart Mill's methods of agreement and difference, the paper combines caseoriented and variable-oriented approaches; it constructs truth tables to scrutinize the roles of network activity and governmental response (or "backlash") in the multi-causality of color revolutions. This method facilitates the analysis of convergent causal prerequisites and conditions.

Forming comprehensive data regarding transnational networks is often difficult due to the various sensitivities pertaining to foreign elements of domestic political phenomena. Nevertheless, the exposure of consequential portions and general illumination of network activities can provide a firm sense of extent and effect. To that end, the paper marshals expenditure data and relevant statistical information from some of the larger international constituents of involved networks (including USAID, E.U., National Endowment for Democracy, Open Society Institute, and so on). The paper, furthermore, cites information from domestic organization websites and other sources to illuminate the nature and scope of their

\footnotetext{
${ }^{21}$ For more detailed explanation, see: Ragin, Charles C.. The Comparative Method: Moving Beyond Qualitative and Quantitative Strategies. Berkeley: University of California Press, 1987.
} 
activity. Academic articles and news reports are used to detail government actions and events of revolutionary periods in the specified cases.

The paper further examines the reaction of the challenged regimes to networks' imposition. Direct and indirect references - passages of domestic criminal codes, laws governing non-governmental activity, and news reports of legislative and executive action - to governmental action underscore notable instances of opposition suppression or authoritarian backlash.

In the case of Russia's 2011 - 2012 movement, the paper incorporates some participant observer methods (resulting from this author's presence in Moscow during the examined events as an intern at Society "Memorial" and an observer of political events and happenings) in part because a significant body of data and analytical work (relative to earlier cases) has not yet emerged regarding the Russian movement. This direct observation contributes to an enhanced accounting of the events and operational activity of transnational network constituents as well as governmental counterparts.

\section{Georgia - The Rose Revolution}

On 2 November 2003, Georgia held national parliamentary elections for just the third time since the end of the Georgian Civil War. Elections in 1995 and 1999 won pluralities for President Eduard Shevardnadze's party, Citizens' Union of Georgia. ${ }^{22}$ During his presidency, Shevardnadze's secured financial assistance from the West and cultivated strong relations with the United States. Despite connections to liberal democracies, Shevardnadze's government exercised enough control over Georgia to be accurately termed "semi-autocratic." Georgian

\footnotetext{
${ }^{22}$ Several other parties that supported President Shevardnadze joined with Citizens' Union of Georgia to furnish the President with parliamentary majorities.
} 
society was generally unmolested by repressive state forces (though with some notable exceptions), but government institutions were opaque and disconnected from the citizenry. Georgia languished domestically under a stagnant and corrupt economy, which was frequently attributed to the wide swath of the economy controlled by members of Shevardnadze's family. Corruption (and nepotism) represented some of the principle charges against the governing regime. By 2003, Shevardnadze's position was considerably weakened: the Citizens' Union of Georgia had lost local elections a few years earlier and recently dissolved after several parliamentary deputies resigned to form other parties; certain media outlets (primarily Rustavi-2) had gained traction with their criticism of the government; and, popular opinion polls that demonstrated the meager support for the ruling regime enfeebled Shevardnadze's authority. ${ }^{23}$ Thus, election results that heralded a resounding victory for the parties supporting Shevardnadze would have been suspect even without the descriptions of mass electoral fraud.

The official election results (those upheld by the Central Election Commission and Shevardnadze) prompted large demonstrations in the Georgian capital, Tbilisi, and several major cities. Persistent activity by the opposition parties and some diplomatic intercession pressured Shevardnadze. He tried to convene the new parliament on 22 November, but fled the plenary session when his speech was interrupted by the entrance of protesters (led by Mikhail Saakashvili) carrying roses. Late the next day, after meeting with opposition leaders, President Shevardnadze announced his resignation. Mikhail Saakashvili’s victory (with $96 \%$ of the vote) in January's emergency presidential election signaled the triumph of the Rose Revolution.

Transnational Networks in Georgia before the Rose Revolution

\footnotetext{
${ }^{23}$ Welt, Cory. “Georgia's Rose Revolution: From Regime Weakness to Regime Collapse.” Center for Strategic and International Studies 1 (2006).
} 
Most accounts portray Georgia before the Rose Revolution - with regards to the rights and liberties exercised by its citizenry - as fairly open. Charges of corruption and government opacity and intractability figured most prominently in charges against the Shevardnadze regime. Assessments of Georgia by USAID in the half-decade preceding the Rose Revolution repeatedly state that, those ongoing problems notwithstanding, "Georgia has a lively free press, and its laws are among the most compliant with Council of Europe (COE) and World Trade Organization (WTO) norms." 24 The benefits of Western - especially United States - military, technological, and economic assistance likely mollified any apprehensions of President Shevardnadze regarding the unfettered activity of media and civil society entities. This included the political scene, where "criticism freely emanated from a number of sources, including political parties across the spectrum, NGOs such as the Georgian Young Lawyer's Association and the Liberty Institute, and print and broadcast media. Thus, a relatively liberal environment within Georgia allowed for the growth and interaction of civil society, including its overtly political elements.

From the beginning of Shevardnadze's term until the elections that spawned the Rose Revolution, international organizations and agencies engaged every sector of Georgian civil society; politically oriented organizations had access to a wealth of resources from foreign purveyors of grants, exchanges, information, and training. Media outlets received grants to develop investigative reporting skills, live news coverage capability, and the mass dissemination of information; political parties, candidates, and youth activists traveled to the U.S. to witness American-style democratic governance, and received training in "message development,

\footnotetext{
${ }^{24}$ See "U.S. Assistance to Eurasia: Georgia" reports in fiscal years (FY) 2000, 2001, 2002, and 2003.
} 
campaign tactics, and constituent outreach., ${ }^{25}$ In half a decade, Georgian NGOs and Western agencies and organizations became deeply interconnected.

Numerous groups participated in the political sector of Georgian civil society with the expressed purpose of promoting greater democratic governance - not an altogether insidious goal, unless you are a semi-autocratic leader. Several prominent organizations coalesced into what can easily be termed a "transnational advocacy network." Major foreign/international entities included: USAID, the Eurasia Foundation, Internews, International Center for Journalists, Soros Open Society Institutes, National Endowment for Democracy, National Democratic Institute, OSCE, International Republican Institute, and the British Council. ${ }^{26}$ The most prominent Georgian presences in this network were the Liberty Institute, Internews Georgia, Rustavi-2 (as well as other burgeoning independent media outlets), the "Kmara" 27 youth advocacy group, the Georgian Young Lawyers' Association, and various opposition political parties and candidates. Using joint ventures and collective initiatives, these entities developed a politically active civil society.

Links between organizations and agencies went through a process that culminated in the “dense connections" ${ }^{\$ 2}$ of a transnational advocacy network in the later years of Shevardnadze's period in office. Early relations were typically of the patron-client variety. For instance, Rustavi-2 originally utilized the Eurasia Foundation for monetary and training resources. In 1996, two years after its founding, Rustavi-2 received a grant of $\$ 9,925.05$ from the Eurasia Foundation. ${ }^{29}$ This initial infusion of capital was bolstered when Rustavi-2, through the Eurasia

\footnotetext{
25 "FY 2001 U.S. Assistance to Eurasia: Georgia" U.S. Department of State. http://www.state.gov/p/eur/rls/rpt/c8491.htm

${ }^{26}$ This represents only some of the most visible, active organizations within this network.

27 "Kmara" means "Enough" in Georgian.

${ }^{28}$ Keck and Sikkink. Activists Beyond Borders.

${ }^{29}$ Anable, David. "The Role of Georgia's Media and Western Aid in the Rose Revolution." The Harvard International Journal of Press/Politics 11, no. 3 (2006): 9.
} 
Foundation, made connections with Internews, an American NGO focused on broadcast media development. By the time of the falsified election in 2003, Rustavi-2 was a close partner of the Eurasia Foundation; the media outlet served as the primary means of broadcasting the discrepancies between the parallel vote tabulations (jointly conducted by the Foundation, USAID, British Council, and the Open Society Institute) and the "official" election results.

The evolution of the Rustavi-2 - Eurasia Foundation relationship was repeated many

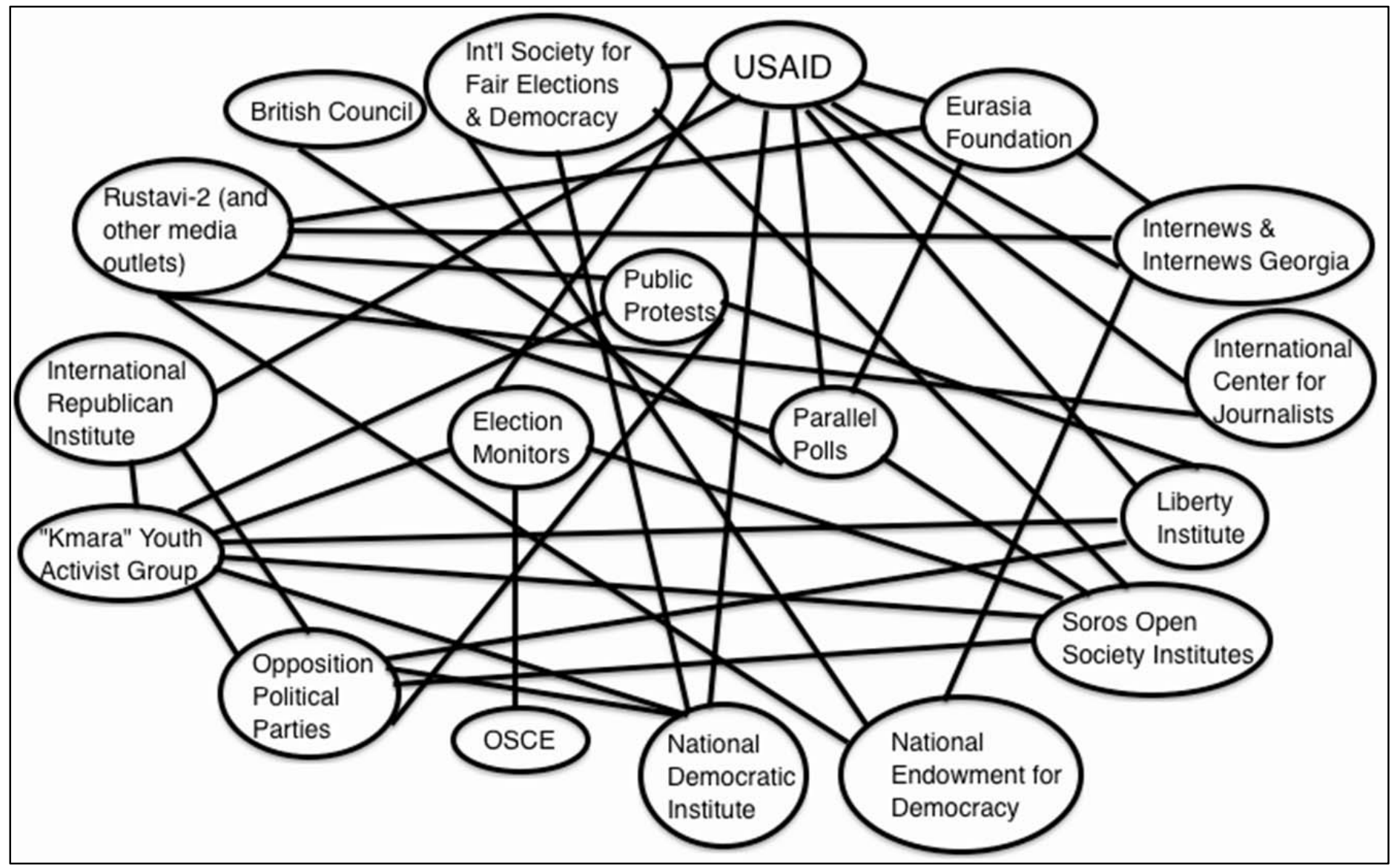

Figure 1: A web partially illustrating the interconnectivity of this transnational advocacy network. (graphic created by author)

times over with several different organizations. Figure 1 depicts the links between these

organizations and some of their multi-party ventures during the Rose Revolution. This frenzied and busy - yet oversimplified - graphic provides some idea of the intricate webs that are created by the constituents of transnational advocacy networks. Once connections are made and become 
entrenched, it is difficult to restrict or curtail the level of interaction, that is, without incurring great domestic and international repercussions.

\section{Network Activity During the Rose Revolution}

The Rose Revolution was a fairly compact political movement. Less than three weeks passed between the fraudulent parliamentary elections and President Shevardnadze's resignation announcement. In this period, the aforementioned network of political organizations was highly active. It constituted the major force in decisive matters that depended on opposition activity (i.e. not factors like "division among the regime's coercive forces"): the ability to identify voting falsification (election monitors and parallel vote tabulation), media to publicize that information, and opposition organized and capable of forming large-scale demonstrations.

Before the election, several organizations had prepared to certify the reliability of the process and veracity of the results. USAID “spent $\$ 1.5$ million to computerize Georgia's messy voter rolls. The U.S. and European governments also gave OSCE money to deploy an unprecedented number of foreign election observers." 30 Furthermore, the National Democratic Institute funded monitors, exit polls, and vote counts through a Georgian NGO, International Society for Fair Elections and Democracy (ISFED). ${ }^{31}$ Sponsored by the Open Society Institute, opposition party leaders and youth activists - including Mikhail Saakashvili and young Georgians who would found Kmara - had visited Serbia to study tactics of the Bulldozer Revolution in 2000, and were thus prepared to confront electoral fraud.

Exit polls conducted during the day and released on election night by Rustavi-2 showed Saakashvili's National Movement party with a plurality of the vote, 20.8 percent, and thus

\footnotetext{
${ }^{30}$ Fairbanks, Charles. “Georgia's Rose Revolution.” Journal of Democracy 15, no. 2 (2004): 114.

31 "National Democratic Institute Publications." National Democratic Institute. www.ndi.org/files/1656_ge_parlelectst_111903.pdf.
} 
positioned to lead the next parliamentary session. ${ }^{32}$ Channel One (the state-owned station), however, showed For a New Georgia (FNG) (and the pro-Shevardnadze bloc) with a narrow advantage and the National Movement with approximately thirteen percent. Counting continued for the next few days, but dissatisfaction and confusion prompted small demonstrations in Tbilisi. Official state results placed the two pro-Shevardnadze parties -FNG and Revival - at the top of the polls: ${ }^{33}$

\section{ISFED Parallel Vote Tabulation}

- National Movement: $26.60 \%$

- FNG: 18.92\%

- Labor Party: 17.36\%

- Democrats: $10.15 \%$

- Revival: $8.13 \%$

- New Rights Party: $7.99 \%$

- Parties under the 7\% threshold: 18.84\%

\section{Central Election Commission Results}

- FNG: $21.32 \%$

- Revival: $18.84 \%$

- National Movement: 18.08\%

- Labor Party: 12.04\%

- Democrats: 8.79\%

- New Rights Party: $7.35 \%$

- Parties under the 7\% threshold: $13.58 \%$

The semi-autonomous republic of Adjara proved decisive as it returned drastically inflated numbers - votes totaling more than its entire population - for Revival party (alternatively known as Union of Democratic Revival, Democratic Union for Revival, or Union for Georgia's Rebirth).

Aslan Abashidze, an authoritarian leader with ties to Russia and separatist inclinations, ruled Adjara and was the founder of Revival party. His leadership, which began in 1991, was born from the regional chaos of Georgia immediately after its independence from the Soviet Union (9 April 1991). Abashidze held strong ties to Russia; over the he "not only allowed the Russian military to maintain bases in Adjara in direct contravention of bilateral and multilateral treaties signed by the central government in Tbilisi concerning their removal, but had cultivated

\footnotetext{
${ }^{32}$ Welt, Cory. “Georgia's Rose Revolution": $16-17$.

${ }^{33}$ Ibid: 18. Opposition parties are underlined (National Movement, Labor Party, Democrats, and New Rights Party). The Labor Party and New Rights Party officially did not participate in the Rose Revolution, instead adopting a neutral position.
} 
the image among citizens of Adjara that the Russian troops were the ultimate protectors of Adjaran semi-independence. ${ }^{, 34}$ Abasidze had nurtured a relationship with the leaders of Moscow and was disposed to influence Georgian affairs (to the extent possible) so as to produce results satisfactory to the Kremlin; in 2003, this disposition meant tipping the scales in favor of Shevardnadze.

After four days of totaling (and tinkering with) the region's votes, the Central Election Commission validated the results from Adjara, which claimed 95 percent turnout. Since 1999, Revival and Abashidze supported Shevardnadze and his parliamentary faction in return for the understanding that Abashidze ruled Adjara with almost complete autonomy. ${ }^{35}$ While this arrangement functionally held together Georgia, a country with several potential breakaway regions, it was a source of Shevardnadze's unpopularity. In November 2003, the notion that Adjara's corrupt returns would be the decisive matter in parliamentary elections simply enraged citizens in Tbilisi and the rest of Georgia.

During the week following the announcement of official results (6 November), the opposition was highly active. The National Movement and Democrats united and, "together with the election monitoring NGO ISFED and the Georgian Young Lawyers' Association, filed legal complaints in over 150 precincts and also lodged official protests against district commissions." 36 A series of small demonstrations and counter-demonstrations materialized in the center of Tbilisi. Several thousand constituents of the opposition protested; government supporters protested in response. The first major protest came on 14 November when upwards of 20,000 assembled in Freedom Square to demand Shevardnadze's resignation and free and fair

\footnotetext{
${ }^{34}$ Goltz, Thomas. Georgia Diary: a Chronicle of War and Political Chaos in the Post-Soviet Caucasus. Armonk, N.Y.: Sharpe, 2006: $114-115$.

${ }^{35}$ Welt, "Georgia's Rose Revolution": 18.

36 Ibid: 21.
} 
elections. While that demonstration bore no direct results, the subsequent appearance of protesters from Adjara - bussed in to voice support for the government - spurred the opposition to continued public protests and campaigns of civil disobedience.

During this time, the international elements of the aforementioned transnational political network assumed the position of observers or detached commentators. Several organizations released statements after the disparities between the official and ISFED vote counts became apparent. The National Democratic Institute, for instance, released a statement recounting the facts and asserting the credibility of ISFED. Yet such statements were limited to a fairly neutral appeal for an easing of political tensions:

NDI calls on President Shevardnadze, the Georgian government and security forces to demonstrate utmost respect for the civil and political rights of all citizens in this tense post-election period. At the same time, the Institute calls on all political leaders to exhort their supporters to respect the rights of others and to act nonviolently. ${ }^{37}$

Whereas U.S. and European organizations represented the more active segment of the network before the fraudulent elections, domestic NGOs and political actors starred in November and the events of the Rose Revolution, but only by virtue of the tools and skills honed with the assistance of foreign partners.

Foreign governments by and large adopted a similar posture, exhorting the conflicting parties to peaceably resolve the crisis without interceding directly. One notable exception: Russian Foreign Minister Igor Ivanov traveled to Georgia in mid-November and played a key role in brokering the resolution. ${ }^{38}$

\footnotetext{
37 “NDI Statement on the Crisis Surrounding Georgia's Parliamentary Elections. November 19, 2003.” National Democratic Institute. www.ndi.org/files/1656_ge_parlelectst_111903.pdf

38 "Georgians party as president steps down - Nov. 23, 2003." CNN.com. http://www.cnn.com/2003/WORLD/europe/11/23/georgia.protests/index.html
} 
By the third week after the elections, events in the capital and across Georgia had reached a fever pitch. Demonstrations, though not swelling beyond tens of thousands, were persistent; political unrest had spread to several other cities; cells of Kmara were clashing with government supporters from Adjara; and, amid this national turmoil, President Shevardnadze moved to convene a new parliamentary session based on the official election tabulations.

As President Shevardnadze began to address the new parliamentary session on 22 November, Mikhail Saakashvili was leading several thousands of protesters north from Freedom Square to the Georgian Parliament Building on Rustaveli Avenue. In the middle of the President's speech, Saakashvili burst through the double doors of parliament and, holding a single rose aloft, demanded Shevardnadze's resignation. Shevardnadze quickly absconded surrounded by his security detail. Several hours later, Shevardnadze declared a state of emergency and prepared to suppress the demonstrations by force. "At 9.30 p.m. (1730 GMT) four armored personnel carriers, more than 10 buses and mini-buses with soldiers took up positions outside Georgia's Interior Ministry." 39 The military and police forces, however, refused to forcibly disperse the protesters and compelled Shevardnadze to meet with the opposition leaders.

In an one-and-a-half hour conference presided over by Igor Ivanov, Saakashvili and Zurab Zhvania (head of the Democrats party) - both former members of Shevardnadze's government, Saakashvili as Minister of Justice and Zhvania as Chairman of parliament convinced Shevardnadze to resign. The announcement late on Sunday 23 November was greeted in downtown Tbilisi with chants of "'He has left, he has left' and celebrated with fireworks."40

\footnotetext{
39 "State of emergency in Georgia." CNN.com. http://www.cnn.com/2003/WORLD/europe/11/22/georgia.protests/index.html

40 "Georgians party as president steps down - Nov. 23, 2003." CNN.com.
} 
Mikhail Saakashvili won January's emergency presidential election with over 95 percent. The National Movement - Democrats coalition secured 67 percent in March's parliamentary elections. And, Georgia moved forward into a post-Rose Revolution government.

\section{Effect of Transnational Networks of Support in the Rose Revolution}

In Georgia, the transnational political network was most important in the run up to the revolutionary period, serving as a preparatory force that laid the groundwork for a democratic uprising. The international influence in the years before the Rose Revolution was indispensible in actuating hitherto latent or underdeveloped political sectors. Foreign agencies served as nodes of connection for other domestic and international organizations concerned with the democratic governance of Georgia. Yet the domestic NGOs and network elements accomplished the Rose Revolution independent of direct guidance by Western affiliates.

In the half decade before the Rose Revolution, the U.S. government alone provided nearly $\$ 800$ million in assistance to Georgia. ${ }^{41}$ This figure includes approximately $\$ 80$ million under the auspices of "democratic reform programs" and the Eurasia Foundation, which do not account for some other services - like exchanges and training programs - that may have imbued Georgians with wishes and designs on democratic reform. USAID, moreover, "budgeted more democracy-related assistance to Georgia in 2002 and 2003 than to any post-Soviet state except the considerably more populous Russia and Ukraine." ${ }^{42}$ The immensity of U.S. government aid combined with democracy-focused assistance from other governments and private NGOs formed an immense arsenal for democratic reformers. President Shevardnadze's toleration of the network development in Georgia, albeit perhaps without a complete understanding of the threat it

\footnotetext{
41 "U.S. Assistance to Eurasia: Georgia" reports.

${ }^{42}$ Welt, "Georgia's Rose Revolution": 40.
} 
represented to his control, ultimately enabled the success of Saakashvili, Zhvania, and the Rose Revolution.

While it was not the only decisive factor (the police forces' refusal to suppress the protests on 23 November numbering among the pivotal circumstances), the determinative role of networks of support cannot be denied in the case of the Rose Revolution. The relationships built, resources shared, and skills acquired in the years before the parliamentary elections were evident in the events of November 2003. Without the foundation provided by the political network of support, the Rose Revolution's manifestation and speedy success are dubious eventualities.

\section{Ukraine - The Orange Revolution}

In 2004, Ukraine was still just another ex-Soviet state striving to find its post-Soviet identity. Ukraine, which has little history of independence to reference, struggled with the pressures and responsibilities of autonomy perhaps more than its neighbors. Divergent interests and perspectives on Ukraine's future divided the country in 2004, especially its geopolitical orientation. In addition to everything else represented by 2004's foremost presidential candidates, Viktor Yushchenko and Victor Yanukovych embodied east-west regional priorities: Yushchenko with domestic and international support in the West, Yanukovych with support in east and south Ukraine and assistance from Russia.

The ten years preceding the Orange Revolution were dominated by one figure: Leonid Kuchma. Elected in 1994 on promises of greater economic reform and progress and expanded trade with Russia, Kuchma slowly repaired Ukraine's ailing economy (that is, mitigated negative growth rates) in his first term. Societal conditions were not the focus of Kuchma's early presidency, but neither did they escape his attention. Ukraine, like many other post-Soviet states, 
benefitted from Western financial assistance, and thus the presiding regime necessarily tolerated a certain amount of foreign aid for democracy, civil society, and independent media. Kuchma nevertheless exercised tremendous control over these sectors; most large media outlets (especially television channels) were controlled by the government or oligarchs aligned with Kuchma's regime; NGO activity was periodically curbed by government campaigns "against both media and civil society freedom.",43

The beginning of Kuchma's second term saw the elevation to prime minister of future opposition leader Viktor Yushchenko. "Pressure from Western donor countries seeking deeper economic reforms" secured the promotion of the erstwhile Governor of the National Bank of Ukraine. ${ }^{44}$ Yushchenko at first cut a somewhat bland figure, that of an unassuming (albeit capable) banker. Ukraine's economy flourished under his policies, reaching nearly six percent GDP growth in 2000 and 9.2 percent in 2001. ${ }^{45}$ His tenure furthermore coincided with successful resolution of "Ukraine's most urgent social problems: wage arrears to teachers, health care workers, and other state employees and overdue pension payments to retirees." ${ }^{\text {,4 }}$

Under the duress of an opposition protest campaign aimed at removing him from office the "Ukraine without Kuchma" campaign - President Kuchma dismissed Yushchenko for fear of his potential political force. The move, however, "transformed him from a technocrat into an opposition leader with a strong public base."47 His party, Our Ukraine, made a strong showing in 2002 parliamentary elections. By 2004 it was clear that the dynamic Yushchenko and the

\footnotetext{
${ }^{43}$ Wilson, Andrew. "Ukraine's Orange Revolution, NGOs and the Role of the West." Cambridge Review of International Affairs 19, no. 1 (2006): 21.

${ }^{44}$ Karatnycky, Adrian. “Ukraine's Orange Revolution.” Foreign Affairs 84, no. 2 (2005): 41.

45 “Ukraine GDP Data \& Country Report | Global Finance.” Global Finance. http://www.gfmag.com/gdp-datacountry-reports/154-ukraine-gdp-country-report.html\#axzz1eXkvtX9o.

${ }^{46}$ Karatnycky, "Ukraine's Orange Revolution": 41.

${ }^{47}$ Ibid.
} 
united opposition - festooned with orange (the color of Our Ukraine) scarves, ribbons, and flags - was well-positioned to defeat Kuchma and his hand-picked successor, Yanukovych.

\section{Transnational Networks in Ukraine before the Orange Revolution}

Activity in Ukraine's non-governmental sphere of politics and regime opposition was periodically inhibited by government interference. The measures employed were usually limited - focusing most frequently on independent media - and temporary, however. Even in cases of media repression, civil society lobbying often dissuaded Kuchma from implementing serious legal restrictions: due to advocacy by the National Association of Broadcasters, for example, "President Kuchma vetoed a media law that would have required TV stations to produce election debates even if an outlet could not afford to do so" (effectively forcing the closure of smaller, independent media stations). ${ }^{48}$ Overall, Ukrainian NGOs and their Western partner agencies and organizations had largely unfettered maneuverability, albeit with sporadic fits of government harassment.

Perhaps by virtue of its geographic importance and large population (approaching 50 million, the second largest post-Soviet state population behind Russia), or perhaps because of its perceived importance in the post-Soviet order of Europe, Ukraine profited from large amounts of democracy assistance and civil society development aid, proportionally more than any other state in the former Soviet Union. In the decade before the Orange Revolution, the U.S. government alone annually provided Ukraine with well over \$200 million, with "democratic reform programs" typically comprising 25 percent of that aid. ${ }^{49}$ Economic aid, moreover, created an expanded middle class, which largely "resented the latticework of corruption that constantly ensnared them - from politically motivated multiple tax audits to shakedowns by local officials

\footnotetext{
48 "FY 2002 U.S. Assistance to Eurasia: Ukraine" U.S. Department of State.

${ }^{49}$ See U.S. Assistance to Eurasia: Ukraine" reports FY 1995 to 2005.
} 
connected to business clans," and thus added to the population disaffected by Kuchma's regime. $^{50}$ Throughout the late 1990 s the Kuchma regime appeared reasonably comfortable in controlling the commanding heights of the government and society (the largest media outlets and important industrial sectors like natural gas were owned, operated, or heavily influenced by the government), while significant opposition development was underway as a result of transnational network development in other sectors of society.

USAID in particular implemented an astounding range of programs. Both directly and through a number of implementing partners and subsidiary organizations, USAID sought to strengthen Ukrainian NGOs and build resilient centers of political activity. The Counterpart Alliance for Partnership, U.S.-EU Transatlantic Initiative, the U.S. Embassy's Democracy Commission, the National Endowment of Democracy, the Eurasia Foundation, and the Freedom House Partnership for Reform in Ukraine (PRU) - all partially funded or enacted by USAID furnished thousands of NGOs with small grant and public policy think tanks (about $\$ 10,000$ on average) in order to promote "youth initiatives and leadership," "engage policy makers," and "battle against corruption." ${ }^{\text {"51 }}$ This last cause particularly engendered an assault on the Kuchma regime, which was seen as the bastion of an endemic system of corruption.

In late $2000 \mathrm{Kuchma}$, reelected just over a year before, was implicated in a massive government corruption and crime scandal. His former bodyguard had surreptitiously recorded and released conversations where "Kuchma is heard dispensing favors, paying massive kickbacks, and conspiring to suppress his opponents - making it clear that the president sat at the head of a vast criminal system." ${ }^{, 52}$ The tapes also incriminated Kuchma in the abduction and murder of journalist Georgy Gongadze three month earlier. This factor severely undermined

\footnotetext{
${ }^{50}$ Karatnycky, "Ukraine's Orange Revolution": 43.

51 "FY 1999 U.S. Assistance to Eurasia: Ukraine" U.S. Department of State.

${ }^{52}$ Karatnycky, "Ukraine's Orange Revolution": 39.
} 
Kushma's already precarious standing. The jailing of former Deputy Prime Minister Yulia Tymoshenko in early 2001 and dismissal of Prime Minister Yushchenko in May further weakened Kuchma.

The revelations of the so-called "Cassette Scandal" energized Ukraine's opposition NGOs and activist groups. Ahead of the 2002 parliamentary elections, activity and connections within Ukraine's opposition political network expanded and flexed its muscles. Ex-Prime Minister Yushchenko joined the growing opposition. He traveled around Ukraine delivering speeches and holding rallies. "These meetings helped create networks of civic and party activists, crucial in the organizing of mass protests." 53 The interpersonal connections created by Yushchenko's personal political activism created the opportunity for domestic and transnational partnerships to form, as well as broadening his base of support and increasing his political capital.

Political party development activity accompanied the pre-election fervor. The NDI and IRI expanded programs to train opposition political candidates and campaigns. Hundreds annually participated in thorough instructional seminars on citizen-oriented politics and election and campaign techniques. Yushchenko's Our Ukraine party was one of many to benefit from these services.

Despite the extreme intimidation tactics exercised by the Kuchma regime, "Ukrainska Pravda ${ }^{54}$ and Ukraine's other independent media outlets did not fold or practice selfcensorship." 55 Yet government "manipulation of broadcasting licenses, restriction of distribution networks, and...revised criminal and civil codes, which allowed individuals and companies to

\footnotetext{
53 Ibid: 44.

${ }^{54}$ Meaning "Ukrainian Truth," is a popular independent internet newspaper, founded by Georgy Gongadze in 2000.

${ }^{55}$ McFaul, "Ukraine Imports Democracy": 61.
} 
sue for defamation on many pretexts" pressured non-state news sources. ${ }^{56}$ In the face of this harassment, U.S. government support almost single-handedly sustained numerous independent media sources in the two years before parliamentary elections. The U.S. Embassy's Media Development Fund offered hundreds of thousands in grant money for non-state newspapers, radio stations, and TV outlets. Internews, funded by USAID, provided more grants as well as training and lobbying services that thwarted the passage of several laws that would have eliminated most independent media.

A slew of other Western governmental agencies and NGOs contributed to the development of civil society and democratic functioning of Ukraine. The Charles Stuart Mott Foundation and the International Renaissance Foundation (funded by George Soros) supported domestic polling agencies. Pora, a student organization modeled on the examples of Otpur (from Serbia) and Kmara, received financial support and training from Freedom House, NDI, IRI, the German Marshall Fund, and the Canadian International Development Agency. ${ }^{57}$ Furthermore, several youth advocates - members of Pora and Znayu - attended seminars on activism and mobilization strategy, "supported by the Alfred Moser Foundation (Netherlands), the Westminster Foundation (UK), and the Fund for European Education (Poland)."

Finally, several international support agencies partnered with a handful of Ukrainian NGOs to mobilize voters and monitor the conduct of the 2002 elections. Most prominently, Committee of Voters of Ukraine (CVU) received assistance from USAID, EU, OSCE, Internews, NDI and others. The CVU produced election-related public service announcements, conducted voter mobilization drives, and trained and deployed a few thousand election monitors. By and

\footnotetext{
${ }^{56}$ Dyczok, Marta. "Was Kuchma's Censorship Effective? Mass Media in Ukraine before 2004.” Europe-Asia Studies 58, no. 2 (2006): 227.

${ }_{58}^{57}$ Wilson, Andrew. Ukraine's Orange Revolution. New Haven: Yale University Press, 2005: 186.

${ }^{58}$ Ibid.
} 
large, these measures were highly effective at monitoring election conduct and fairness. The consensus of international and domestic monitors was that the parliamentary election was free and fair.

Our Ukraine won nearly a quarter of parliamentary seats, the most of any one party in the 2002 elections. The Ukrainian parliament remained somewhat independent of Kuchma as a result of the election, a fact that would prove integral to Yushchenko's tactics during the Orange Revolution. The efficacy of the various preliminary and election measures of NGOs, political parties, and independent media outlets prompted "another anti-NGO campaign through the winter of 2003-4, this time backed by Kuchma's new strong-arm Chief of Staff Victor Medvedchuk and his normally reliable allies, the Communist Party of Ukraine." ${ }^{59}$ The transnational political network was by now firmly established, however.

Examination of the opposition political sphere at this juncture reveals a resilient network that, with little alteration (the most notable exception being the 2003 creation of the Channel 5 television station), would lead the Orange Revolution in two and a half years. The major constituents included:

International Actors
The U.S. (especially USAID)
European Union
NDI
IRI
Internews
Eurasia Foundation
Freedom House
OSCE
NED
ENEMO
German Marshall Fund
Westminster Foundation

Domestic Actors ${ }^{60}$

Committee of Voters of Ukraine (CVU)

Democratic Initiatives Foundation

Znayu

Kiev International Institute of Sociology (KMIS)

Razumkov Centre

U.S.-Ukraine Foundation

Radio Era, Radio Kiev, and Radio Gala

Our Ukraine party

Yulia Tymoshenko Bloc

Chysta Ukraina ('Proper Ukraine')

Black Pora*

Yellow Pora*

\footnotetext{
${ }^{59}$ Wilson, "Ukraine's Orange Revolution...": 22.

${ }^{60}$ Asterisked actors were established after the 2002 parliamentary elections

${ }^{61}$ The European Network of Election Monitoring Organizations
} 
Liberty Institute Channel 5*

Canadian International Development Agency

World Bank

Charles Stewart Mott Foundation

Soros's International Renaissance Foundation

Swedish International Development Cooperation Agency

These actors collaborated closely in the interlude between the parliamentary elections and 2004's presidential vote. Some parts of this network even formalized their association, such as the Freedom of Choice Coalition, which was comprised of several Ukrainian NGOs and opposition groups. This combined resources of many NGOs produced an authoritative election monitor and analysis hub (through a website, www.campaign.org.ua), especially effective at tracking campaign spending. ${ }^{62}$

The success of Our Ukraine made Yushchenko the opposition's frontrunner for the presidency. A weak showing by Yulia Tymoshenko's party, moreover, prompted her to align with Our Ukraine and support Yushchenko's bid, rather than running herself in 2004.

The encouraging results in 2002 stimulated an upsurge in opposition activity and international support. Our Ukraine's strong showing activated hitherto passive international elements. Even as the U.S. scaled back its overall aid to Ukraine - corresponding to a general deterioration of relations with Kuchma - democratic assistance remained fairly high and indeed seemed larger to the opposition, which was receiving a greater proportion of the resources. Consistent government corruption and money laundering at the expense of U.S. political party and governance development prompted a reallocation of resources:

The [aid and development programs operated by USAID subsidiaries and partners] benefitted all the main political parties, including supporters of both Yushchenko and Yanukovych, and even many of the fake parties set up by supporters of Yanukovych. A large proportion of foreign funding therefore rightly went to the government side, yet it was the government side that was often

\footnotetext{
${ }^{62}$ Wilson, Ukraine's Orange Revolution: 75, 119.
} 
accused of removing monies for partisan use or personal benefit. This was one reason for the scale-back of funding in 2003; the West was increasingly reluctant to fund projects involving compromised, high state officials. A partial consequence was that the West worked more with the regime's critics thereafter. ${ }^{63}$

While the U.S. earmarked a greater share of its resources to the opposition political sector, other international actors committed greater capital and assets to Ukraine. For instance, Soros's

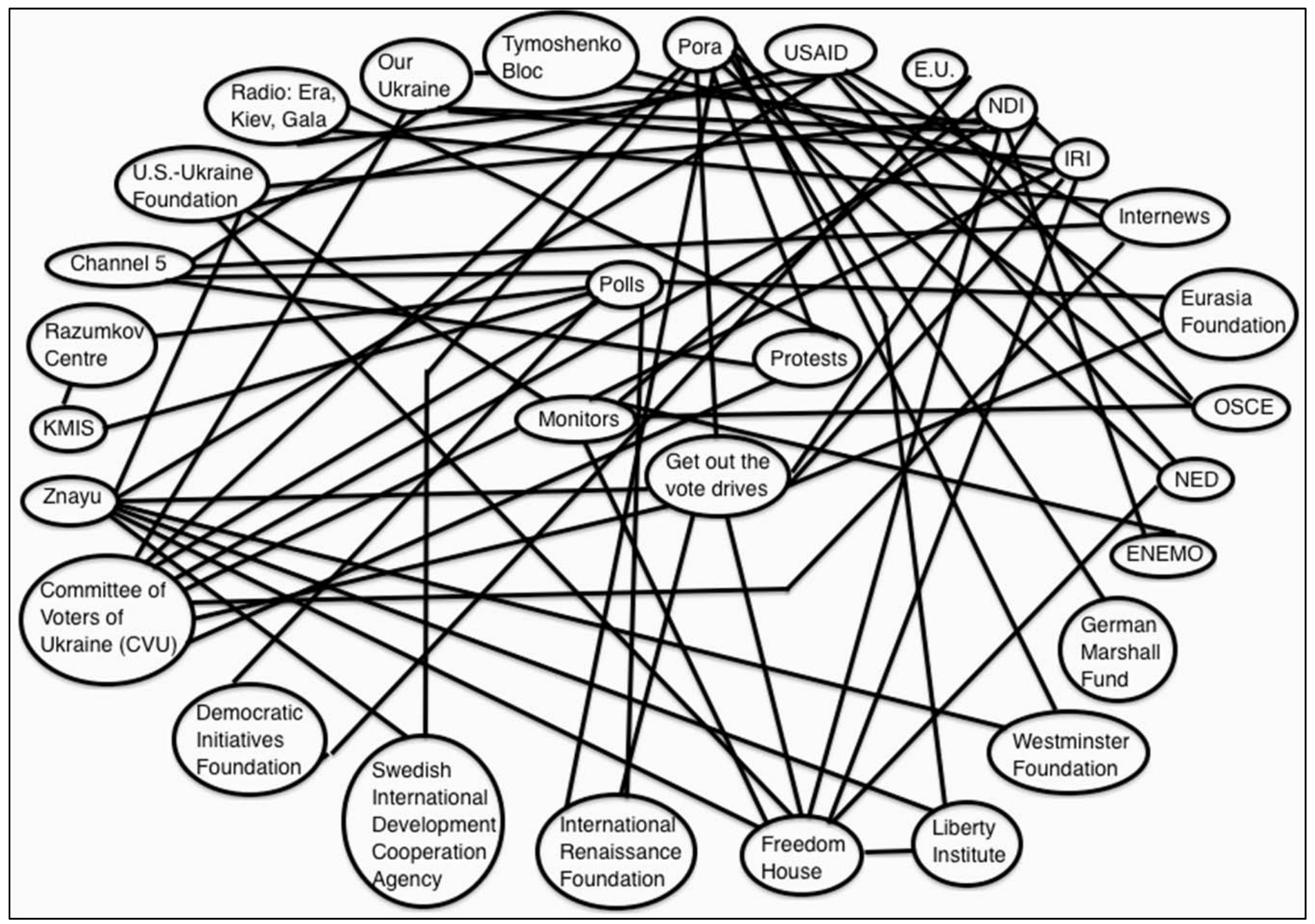

Figure 2: A web partially illustrating the interconnectivity of this transnational advocacy network. (graphic created by author)

International Renaissance Foundation spent “\$1.65 million between Autumn 2003 and December

2004 " in support of the Freedom of Choice Coalition and activist opposition groups. ${ }^{64}$

\footnotetext{
${ }^{63}$ Wilson, “Ukraine's Orange Revolution...": 25.

64 Ibid: 23.
} 
Domestic parts of the network responded to this bolstered support not only by intensifying their projects and pre-election preparations, but also by expanding. Petro Poroshenko, an ally of Yushchenko, established Channel 5; it covered both campaigns (as opposed to the state-owned media that had largely ignored Yushchenko) and usually portrayed Our Ukraine in a positive light. Although Channel 5 had a broadcast reach of only 37 percent $^{65}$ (only available on cable), "it was popular in Kiev and several other cities" from whence the preponderance of support for the revolution would originate. ${ }^{66}$

Training sessions and lessons from former leaders of Kmara (Georgia) and Otpur (Serbia) led to the creation of Pora (meaning "It's time"), a Ukrainian youth activism organization with two wings: Yellow Pora, a political party focused on the continued diffusion of youth activism tactics, and Black Pora, a domestically-focused body geared toward unseating Kuchma.

The government, however, did launch several efforts aimed at curtailing this activity and obstructing Yushchenko’s operations. At Kuchma's behest in December 2003, the parliament established "an ad hoc commission to investigate foreign and foreign-funded NGOs involved in election-related activities." ${ }^{67}$ Yushchenko was attacked and impeded in several ways in the year before the election. Government-controlled media berated him many times over; obstructing or harassing his travels; and, regime forces were likely behind the poisoning of Yushchenko with dioxin that nearly killed him and permanently scarred his face.

Stunningly, opposition activity proceeded apace, irrespective of harassment from the coalition of forces marshaled by Kuchma, Yanukovych, and the Putin regime, which provided advice and assistance to Kuchma and Yanukovych. Almost every member of the opposition

\footnotetext{
${ }^{65}$ Dyczok, “Was Kuchma's Censorship Effective?”: 238.

${ }^{66}$ Karatnycky, "Ukraine's Orange Revolution": 44.

67 “FY 2003 U.S. Assistance to Eurasia: Ukraine" U.S. Department of State.
} 
political network participated in massive voter mobilization campaigns. Funded and operationally assisted by USAID and the U.S.-Ukraine Foundation, Znayu conducted extensive "voter education and get-out-the-vote efforts, recognized by friends and foes as contributors to Yushchenko's electoral success." ${ }^{\circ 8}$ A joint initiative by Freedom House, NDI, IRI, and the U.S.Ukraine Foundation performed similar services in conjunction with local NGOs.

The CVU, Pora, Our Ukraine, Internews-Ukraine also took steps to win over the public support of Western governments ahead of the election. "Elite networks between Our Ukraine leaders and Western leaders nurtured Our Ukraine allies in the West when debates erupted in Washington and European capitals about how to respond to the Orange protesters.",69

In sum, the U.S. and other Western governments spent approximately $\$ 65$ million in 2003 and 2004 in direct support of the opposition, and over \$18 million in election-related assistance. Private organizations and donors added several millions more. By the first round of the presidential election on 31 October 2004, a trained, experienced, and well-equipped opposition network stood ready to enforce its democratic prerogatives.

Network Activity During the Orange Revolution

From the first round of voting on 31 October to the second round revote on 26 December, the transnational democracy network in Ukraine deployed immense resources to monitor and tabulate the election, protest fraud and illegitimacy, and seek redress of evidence-based grievances. Network activity peaked in the months of November and December 2004 as the sinewy bonds connecting its constituents flexed in order to safeguard Ukrainians' electoral rights.

\footnotetext{
${ }^{68}$ McFaul, "Ukraine Imports Democracy": 58, 69.

${ }^{69}$ Ibid: 74.
} 
Several NGOs recruited and trained election monitors and observers. The CVU, with funding and instructional assistance from USAID and NDI, "fielded 10,000 domestic monitors (accredited as journalists) for each round of the 2004 Presidential elections."70 The OSCE, IRI, NDI, and the U.S.-Ukraine Foundation deployed several hundreds of international observers. And, NDI and Freedom House secured the involvement of a large ENEMO monitoring team, "which comprised 1,000 observers from seventeen electoral monitoring organizations in formerly communist countries." $" 71$ As part of its mission, a detachment of the ENEMO team "visited 4,392 polling stations and more than 200 of the 225 territorial election commissions" during the second round of voting. In total, more than 12,000 observers monitored Ukraine's Presidential elections, a staggering number unmatched in post-Soviet history.

The other main voting day measures were exit polling and parallel vote tabulation. "Eight Western embassies (the U.S., U.K., Canada, the Netherlands, Switzerland, Norway, Sweden, and Denmark) and four NGOs (the NED, Charles Stewart Mott Foundation, Eurasia and George Soros's Renaissance Foundation), helped fund the exit polls in each of the three rounds," 72 coordinated by the Democratic Initiatives Foundation and conducted by the Kiev International Institute for Sociology (KMIS) and the Razumkov Centre. ${ }^{73}$ The CVU organized a parallel vote count and its own exit poll. These exhaustive methods formed the vanguard of vote legitimacy battle in Ukraine.

The magnitude of the efforts were not excessive either; after a first round of voting significantly less tainted by electoral irregularities (wherein Yushchenko and Yanukovych each received approximately 39 percent), the observers, monitors, and pollsters encountered a second

\footnotetext{
70 "FY 2004 U.S. Assistance to Eurasia: Ukraine” U.S. Department of State.

${ }^{71}$ McFaul, "Ukraine Imports Democracy": 76.

${ }^{72}$ Wilson, “Ukraine's Orange Revolution...": 26.

${ }^{73}$ Note: the SOCIS Center and the Social Monitoring Center participated in round one, but split before round two after accusation of manipulating the results in favor of the government and Yanukovych campaign.
} 
round (on 21 November) rife with sophisticated barrages of voting fraud and election rigging. First of all, votes were falsified at the precinct level (i.e. the lowest level of the voting system) through stuffing of the ballot box, "carousel" voting, the removal of votes for Yushchenko, and pens filled with disappearing ink in areas of high support for Our Ukraine - where it is most difficult to trace. These methods were not exposed by the CVU's systematic vote tabulation, which relied on figures reported by the precincts. Election monitors, however, noted these activities and recorded evidence that would prove integral in Yushchenko's follow-on legal appeals. In addition to those precinct-level falsifications, the Central Election Commission (CEC) inflated turnout in the eastern regions (especially Donetsk and Luhansk) that supported Yanukovych, adding "approximately 1.2 million new votes - well over 90 percent of which went to the regime's favorite."74 Exit polls, by KMIS and the Razumkov Centre and by the CVU, accounted for and discarded practically all falsification and showed Yushchenko with a 53 - 44 percent lead over Yanukovych, a stark contrast to the official figures: a 49 - 46 victory for Yanukovych; "the exit poll established what was credible, and what was not."75 The CVU claimed that 85,000 local officials conspired in the government's fraud, resulting in over 2.8 million counterfeit votes for Yanukovych. ${ }^{76}$

It should be noted that a few members of Ukraine's Security Service (SBU) aided the opposition's detection of electoral fraud. "In the days before and after the runoff vote, a highranking SBU official had kept in regular contact with Oleh Rybachuk, Yushchenko's chief of staff," as the liaison for the SBU operatives which gathered intelligence about ploys to rig the election by the Kuchma regime. ${ }^{77}$ This intelligence gathering included wiretaps on calls between

\footnotetext{
${ }^{74}$ Karatnycky, “Ukraine's Orange Revolution”: 36.

${ }^{75}$ Wilson, "Ukraine's Orange Revolution...": 27.

${ }^{76}$ Karatnycky, “Ukraine's Orange Revolution”: 37.

${ }^{77}$ Ibid: 37.
} 
Viktor Medvedchuk and Yuri Levenets, a Yanukovych campaign advisor, where the two colluded in schemes of mass voter fraud. The evidence collected by the SBU would prove vital to the Yushchenko campaign's voter fraud suit to the Supreme Court.

Cries of foul play arose in the middle of Election Day from the Yushchenko camp, which called for mass demonstrations to prevent the government from completing its fraud. Independent media outlets significantly aided this call to action by publicizing the disparate results of the exit polls and the CEC's official count. Channel 5 and Ukrainska Pravda experienced huge spikes in their audiences in the days after the vote since they were reporting the struggle underway. Responding to the Yushchenko campaign and independent media, over a hundred thousand turned out in the evening on 21 November to denounce the electoral fraud.

Protests erupted in several other cities the next day, including upwards of 500,000 in Kiev. Amidst that chaos, "Yushchenko declared himself president and took the oath of office in an abbreviated session of parliament." owned television stations, which were pressured by the success of Channel 5 to cover the opposition movement.

Public demonstrations grew, nearing a million in Kiev. A "tent city" was set up on a street adjoining the centrally-located Independence Square, also known simply as "Maidan." This massive and continual street presence, largely maintained by Pora activists and a few key NGOs, sustained the protest movement and appreciably complicated the logistics of government suppression. McFaul writes:

Kuchma and his supporters, including those in Moscow, did contemplate using coercion to stay in power. Measuring the distribution of power between state and society, however, was not an abstract exercise during the Orange Revolution; calculations about power could be made based on concrete assessments of crowd sizes

\footnotetext{
${ }^{78}$ Ibid: 45.
} 
and unified will among those in the state wielding coercive power. Democratic society was simply too powerful to repress. ${ }^{79}$

The pressure of hundreds of thousands of nearby protesters coupled with appeals from the Yushchenko campaign convinced the CEC to defer to the parliament rather than proceed with the certification of the vote. The parliament, in turn, sent the issue to the Supreme Court. Deciding on 3 December 2004, "the court used evidence of fraud collected by the CVU and other NGOs to annul the official results and call for a replay of the second round later that month." ${ }^{80}$ Parliamentary speaker Volodymyr Lytvyn, aided by the Presidents of Poland and Lithuania and the E.U.'s Foreign Affairs Commissioner, "brokered the specifics of a comprehensive agreement. It featured significant new protections in the election law to reduce the potential for voter fraud. ${ }^{.81}$

After a generally more open (most notably in terms of media coverage) miniature campaign, Ukrainians cast their ballots for President once again on 26 December. The regional divisions remained; Yushchenko won the west and center of the country, Yanukovych the east and south. The much cleaner election resulted in a $52-44$ percent victory for Yushchenko, mirroring exit poll results from a month earlier. President Yushchenko's inauguration on 23 January 2005 completed the Orange Revolution.

\section{Effect of Transnational Networks of Support in the Orange Revolution}

In the months after his inauguration, Yushchenko and his campaign team thanked foreign support, especially from the United States, for Ukraine's democracy, civil society, independent media, and so on. Western influence both directly and through domestic organizations arguably prevented Ukraine from devolving into a full authoritarian system, and instead limited it to a

\footnotetext{
${ }^{79}$ McFaul, "Ukraine Imports Democracy": 52.

${ }^{80}$ Ibid: 60 .

${ }^{81}$ Karatnycky, “Ukraine’s Orange Revolution”: 46.
} 
vulnerable semi-authoritarian scope. The large proportion of foreign funding in civil society "by some estimates, at least 80 percent" $" 82$ - created a large sector with ties to liberal democracies of the West rather than the Kuchma regime. "Intellectual and financial imports from the West helped to strengthen Ukraine's democratic opposition and offset resources transferred from Russia” in support of Kuchma and Yanukovych, ${ }^{83}$ which some estimate at more than $\$ 410$ million (in campaign and election support alone). ${ }^{84}$ That the opposition network prevailed against this massive injection of Russian funds for Yanukovych (much more than aggregate Western support for Yushchenko in the election year) speaks to the strength of a well-trained and active network.

The highly visible division of international support - the West for Yushchenko, Russia for Yanukovych - rhetorically factored in Ukraine's campaign as well. Support from the U.S. for Yushchenko prompted derisive remarks from the Yanukovych camp such as referring to him as "Bushenko." Yet the sentiment underlying such jeers most likely denoted wider appeal for Yushchenko; that is, a majority of Ukrainians consider themselves European and their country rightfully placed in the company of the West. NGOs and local organizations that received Western support also gained a sort of perceptional boost, an extensively attractive seal of approval from the West. While it certainly would not help in eastern Ukraine, where greater sympathy for Russia predominates, the perception of Yushchenko and the opposition network as Western probably won them support in contentious electoral regions.

However, there appears to be no evidence to support the theory that Western donor organizations and agencies unevenly distributed aid and grants. Indeed, some foreign

\footnotetext{
${ }^{82}$ D'Anieri, Paul J.. Orange Revolution and Aftermath: Mobilization, Apathy, and the State in Ukraine. Washington, D.C. Woodrow Wilson Center Press, 2010: 242.

${ }^{83}$ McFaul, "Ukraine Imports Democracy": 72.

${ }^{84}$ Wilson, "Ukraine's Orange Revolution": 30.
} 
governmental entities may have insisted on regional balance of assistance so as to avoid recriminations of outright bias. The recipient domestic actors are fairly accorded responsibility for the manner in which outside assistance was used. The east-west division in Ukraine's Orange Revolution was symptomatic of longstanding regional differences and largely unaffected by the Western democratic donors.

More so than in Georgia, the ruling Ukrainian regime challenged the transnational network with measures aimed at restricting their activity. While the authoritarian backlash of Kuchma's regime did not quite equal other cases (as the examples of Belarus and Russia will show), the pressure exerted was significant and testifies to the strength of the democracy network.

In the delicate balance of governmental and societal forces in Kuchma's semiauthoritarian regime, the influence of external constituents of the democracy network was significant. As those organizations curbed Ukraine authoritarian development, they simultaneously strengthened the media, opposition parties, civic organizations, and activist groups, all of which were vital factors in the success of the revolutionary movement.

"The Orange Revolution was a contentious struggle for power between a semi-autocratic regime and a democratic opposition, in which the opposition had enough power - the necessary strategies, resources, and popular support - to prevail." ${ }^{\text {} 85}$ The development of democratic opposition by Western resources and the formation of lasting partnerships and connections precipitated the defeat of governmental forces. Effects of the examined transnational advocacy network were fundamental to the democratic victory in the Orange Revolution.

\footnotetext{
${ }^{85}$ McFaul, “Ukraine Imports Democracy”: 80.
} 


\section{Belarus - The Denim Revolution ${ }^{86}$}

Belarus represents one of the most politically backward and stagnant cases of the former Soviet Union. Whereas its closest ally - the Russian Federation - experimented with liberal democracy in the 1990s, Belarus elected Alexander Lukashenko to the presidency in 1994 and now, nearly twenty years later, he remains the leader of Belarus. Obviously, the democratic norm of constitutional term limits is not present in Belarus; that is, President Lukashenko got rid of them in a controversial referendum in 2004 (shortly before the end of his hitherto maximum second term in office). Though it is a fully authoritarian state, Belarus has held regular elections since the adoption of its constitution in 1994. These democratic procedures in an otherwise undemocratic state have served as flashpoints of Belarusian opposition activity, including the socalled "Denim Revolution" movement after the 2006 presidential election.

Alexander Lukashenko's early post-Soviet political career had two definite characteristics: a uniquely reactionary stance on Belarusian independence and a record of anticorruption. He gained prominence as the head of an anti-corruption commission, where he issued largely unsubstantiated (though not incredible) charges of corruption to scores of highranking officials - including the Defense Minister, two vice-premiers, and the speaker of the parliament. ${ }^{87}$ As for the former characteristic, "Mr. Lukashenko prided himself on the fact that he was the only political leader from the country who voted against the Brest pact of 1991, which proclaimed the end of the Soviet Union." 88

Despite Lukashenko's steady consolidation of power, opposition activity persisted in Belarus. Public protests sprang up around the presidential election of 2001 and the parliament

\footnotetext{
${ }^{86}$ Alternatively known as the "Jeans Revolution" or the "Cornflower Revolution."

${ }^{87}$ Specter, Michael. "Belarus Voters Back Populist in Protest at the Quality of Life.” The New York Times, June 25, 1994. http://www.nytimes.com/1994/06/25/world/belarus-voters-back-populist-in-protest-at-the-quality-of-life.html. ${ }^{88}$ Ibid.
} 
and referendum votes of 2004. Protests and opposition activity proceeded apace in the months before the 2006 presidential election. During one of the more notable demonstrations, in Minsk on 16 September 2005, police confiscated protesters' independence flags; ${ }^{89}$ Mikita Sasim, a youth activist, responded by removing his jean (or "denim") shirt and using it as a flag. An extremely popular product in the former Soviet Union, denim evoked not only this incident, but also the West. It quickly became one of the opposition's key symbols, combining an object of preexisting cultural importance with a tactic borrowed from other color revolution movements; mobilization efforts typically contained statements like "Come out in the streets of your cities and towns in jeans!"90

On the night (19 March) of the 2006 presidential vote, a huge crowd - estimated between 15,000 and 20,000 - formed in October Square in downtown Minsk. Those assembled supported the united opposition candidate Alexander Milinkevich (or else, opposed Lukashenko) and cried foul the official election results which declared Lukashenko the victor with 83 (or as much as 86) percent.

For the next week, October Square was occupied by a fluctuating, though nevertheless continuous group of denim-clad revolutionaries. On 25 March, the movement ended with a frenzied clash of protesters and riot officers on Okrestina Street. What opposition network, if any, was at work in the Denim revolution; why did it fail to change the Belarusian regime?

Transnational Networks in Belarus before the Denim Revolution

Aside from a brief reprieve in the early 1990s under the leadership of Stanislav Shushkevich, Belarus never experienced the sort of post-Soviet recession of governmental

\footnotetext{
${ }^{89}$ The Belarusian independence flag - two horizontal white bars split by one red bar - came from the roughly sixmonth period of independence in 1918, before Belarus fell under the control of the Soviet Union.

${ }^{90}$ Sector, Charlotte. "Belarusians Wear Jeans in Silent Protest." ABCNews.com. http://abcnews.go.com/International/story?id=1502762 (emphasis added by author).
} 
control - which typically engendered civil society and opposition development - that occurred in the rest of Eastern Europe. Alexander Lukashenko's ascension to the presidency heralded anticorruption, a focus on economic growth, and above all stability. Like all other former Soviet republics, Belarus's economy in the early 1990s was marred by negative growth and corruption. Reversal of these trends represented Lukashenko's foremost governing mandate, which he not unreasonably associated with stability. That guiding principal, asserted Lukashenko, meant a return (or the closest arrangement) to its indissoluble connection to Russia and the elimination of opposition, either to that plan or anything else he decided upon.

Referenda in 1995 and 1996 acted on these judgments, reinforcing economic ties with Russia and emasculating parliament, practically the only institution capable of countering the power of the presidency. These developments and criminal code reform aimed at restricting Belarusian society resulted in the adoption of a policy of selective engagement by Western countries. The E.U. restricted its aid to Belarus, in the words of the European Neighborhood and Partnership Instrument, "to humanitarian or regional projects or those which directly support the democratization process." 91 Similarly, "virtually all U.S. Government assistance to Belarus is targeted at the country's non-governmental sector, particularly those NGOs that are working to promote the development of civil society and the free flow of information." 92 The total aid package of the Western governments, therefore, was significantly less than any other country in the region.

Furthermore, whereas the level of private organizations and funds from abroad ranged from small to considerable elsewhere in the post-Soviet space, it was essentially non-existent in Belarus. George Soros, for example, established a branch of his foundation in Belarus in 1994.

\footnotetext{
91 "Belarus - Country Strategy Paper 2007-2013.” European Neighborhood and Partnership Instrument (2006). ec.europa.eu/world/enp/pdf/country/enpi_csp_nip_belarus_en.pdf: 15 .

92 "FY 2000 U.S. Assistance to the NIS: Belarus." U.S. Department of State.
} 
However, harassment through tax audits and resulting fines amounting to $\$ 3$ million forced its closure in September 1997, ending roughly three years of support (encompassing \$13 million) in Belarusian education, ecology, health care, and civil society. ${ }^{93}$ Other private organizations forced out of Belarus by government persecution include even the most innocuous NGOs, such as the "United States-based City of Hope, which distributes food and clothing in Belarus, and the German-financed Chernobyl Children's Fund."94 Thus, even before the rash of color revolutions in the former Soviet Union, Lukashenko had instituted policies of "authoritarian backlash."

Before detailing the networks that underwrote the Denim Revolution, we must examine the state-controlled parameters that circumscribed non-governmental activity. Unencumbered by the notions of integration with the West that had somewhat restrained Shevardnadze and Kuchma, President Lukashenko created an extensive legal system to control society. Changes to the Belarusian constitution and criminal code in the 1990s established great latitude for the state and its security apparatus - comprised of the KGB, Internal Affairs agencies, Presidential Security Service, Ministry of Defense, and border police - in combatting terrorism, preventing money laundering, and regulating the movement of assets within and across the country's borders. Decrees issued by Lukashenko further restricted activity; Presidential Decree No. 8: "On the Registration Procedure for Foreign Gratuitous Aid" instituted strict regulations on the influx of foreign aid to non-governmental organizations. In sum, the Belarusian government had an extensive and complex legal system that could be easily stretched and construed to pursue targeted NGOs and political parties.

\footnotetext{
93 Miller, Judith. "Belarus Fines Soros Foundation \$3 Million in Apparent Crackdown.” The New York Times, May 2, 1997. http:/www.nytimes.com/1997/05/02/world/belarus-fines-soros-foundation-3-million-in-apparentcrackdown.html

94 Ibid.
} 
Surreptitious means of repression accompanied these legal developments. Several opposition politicians, human rights activists, and critics of the regime have disappeared during Lukashenko's tenure. Opposition figures of obvious popularity and significant influence vanished, like Yury Zakharanka (former Interior Minister) and Viktor Gonchar (a former deputy prime minister). Vocal critics too went missing; Dmitri Zavadsky, a cameraman who had covered Lukashenko and later the conflict in Chechnya, "accused government ministers of selling arms to Chechen rebels fighting against Russia" 95 disappeared on 7 July 2000; businessman and philanthropist Anatol Krasouski supported Viktor Gonchar and went missing the same day as him, on 16 September 1999. This sort of Stalinist activity represented the Lukashenko regime's most intimidating, though not infrequently used, tools.

The government took further steps to confine opposition activity in the months ahead of the 2006 election. "A new housing code in early 2005 led to the closing of nearly three-hundred local political-party offices that had been lodged in residential properties but which found themselves forced by the change to seek space in hopelessly overpriced office buildings." 96 A new law required the registration and licensing of NGOs and specified activities. "Running an unregistered NGO, training people in mass-protest techniques, organizing an NGO or political party said to 'hamper execution of its members' work and family duties,' or 'defaming' the Belarusian republic in the international arena" numbered among the new prohibitions, punished by fines and jail terms of up to three years. ${ }^{97}$ Pavel Seviarynets, the leader of Young Front $-\mathrm{a}$ youth activist group similar to Kmara and Pora - was one of many opposition figures arrested due to purported violations of this new portion of the criminal code. In May 2005, he was

\footnotetext{
95 Osborn, Andrew. "Dissidents of the theatre in Belarus pin their hopes on the denim revolution." The Independent (London), March 9, 2006.

${ }^{96}$ Silitski, Vitali. "Belarus: Learning From Defeat.” Journal of Democracy 17, no. 4 (2006): 140.

${ }^{97}$ Ibid.
} 
sentenced to two years or corrective labor in Maloye Sitna, a tiny village near Belarus's northern border with Russia. ${ }^{98}$ In effect, several influential opposition figures like Seviarynets were exiled to the periphery of Belarus, far from the centrally located Minsk, for the months before and after the presidential vote.

Nevertheless, that vast arsenal of repressive mechanisms notwithstanding, a small but resilient transnational network of opposition operated in Belarus. Its size and scope were significantly less than its "rose" and "orange" counterparts. Indeed, it is much easier to form a nearly comprehensive list of its constituents:

International Actors
The U.S. (especially USAID)
European Union
NDI
IRI
NED
Internews
Eurasia Foundation
Freedom House
OSCE
Counterpart Alliance for Partn
ABA/CEELI
U.N. Development Program
International Labor Org.
European Radio Belarus

Domestic Actors

Zubr (meaning 'Bison'), a youth activist group Young Front Charter 97 IISEPS Office for a Democratic Belarus Partnership Belarusian Initiative Center Belarusian Association of Journalists Narodnaya Volya, Nasha Niva, Belarusy i Rynok (newspapers)

United Civil, 'Fair World,' Social Democrats, Popular Front (political parties) Independent Trade Union, Free Trade Union, Organization of Working Women (unions)

In the decade before the Denim Revolution, the U.S. government and its agencies (including USAID, NDI, IRI, Eurasia Foundation, and NED) spent over \$250 million in support to Belarus. ${ }^{100}$ About half of this assistance was in the form of humanitarian aid from the U.S. Department of Defense and privately donated commodities. The other half - or approximately $\$ 125$ million - funded typical operations, though on a much smaller scale than in previous cases.

\footnotetext{
${ }^{98}$ Kalinovski Square. Film. Directed by Yury Khashchavatski. United States: Garden Thieves Pictures, 2009.

99 The American Bar Association's Central and Eastern European Law Initiative.

${ }^{100}$ See "U.S. Assistance to Eurasia/NIS: Belarus" reports in fiscal years (FY) 1996 - 2006.
} 
IRI and NDI worked closely with local branches of the major opposition parties, and conducted training and seminars through organizations like the Belarusian Initiative Center. USAID-funded Internews projects engaged local television stations - though this ultimately proved ineffectual as the medium of television was the primary tool of Lukashenko's propaganda and therefore was tightly controlled by the state. USAID worked with most of the nation's print media, including the major opposition newspapers: Narodnaya Volya ("the People's Will"), Nasha Niva (“Our Field" or "Our Land"), and Belarusy i Rynok ("Belarus and Market"); a large part of the focus was adapting the newspapers to web-based formats, a policy that has had farreaching consequences in Belarusian opposition activity. The American Bar Association through its CEELI program provided legal advice and assistance to NGOs and political parties, mitigating the strain of government harassment. Grants from the U.S. Embassy, Eurasia Foundation, NED, and Freedom House provided thousands of grants "in support of independent print and electronic media, youth and women's groups, human rights groups, independent trade unions, and other pro-democracy organizations."101

The E.U. provided some minor support as well. Approximately $\$ 11$ million (€8 million) in TACIS (Technical Aid to the Commonwealth of Independent States) funds went to Belarus in 2005-2006. ${ }^{102}$ Over $\$ 7$ million of these funds went into projects that supported education, training, media, and other forces for democratization. The E.U.'s main implementing partners in these ventures were the OSCE and the U.N. Development Program.

\footnotetext{
101 "FY 2001 U.S. Assistance to the Eurasia: Belarus." U.S. Department of State.

102 "Belarus..." European Neighborhood and Partnership Instrument: 16.
} 
Perhaps the most notable aspect of the transnational network at work in 2006 was its very evident attempts to formalize sub-networks. The major opposition political parties, acting on the

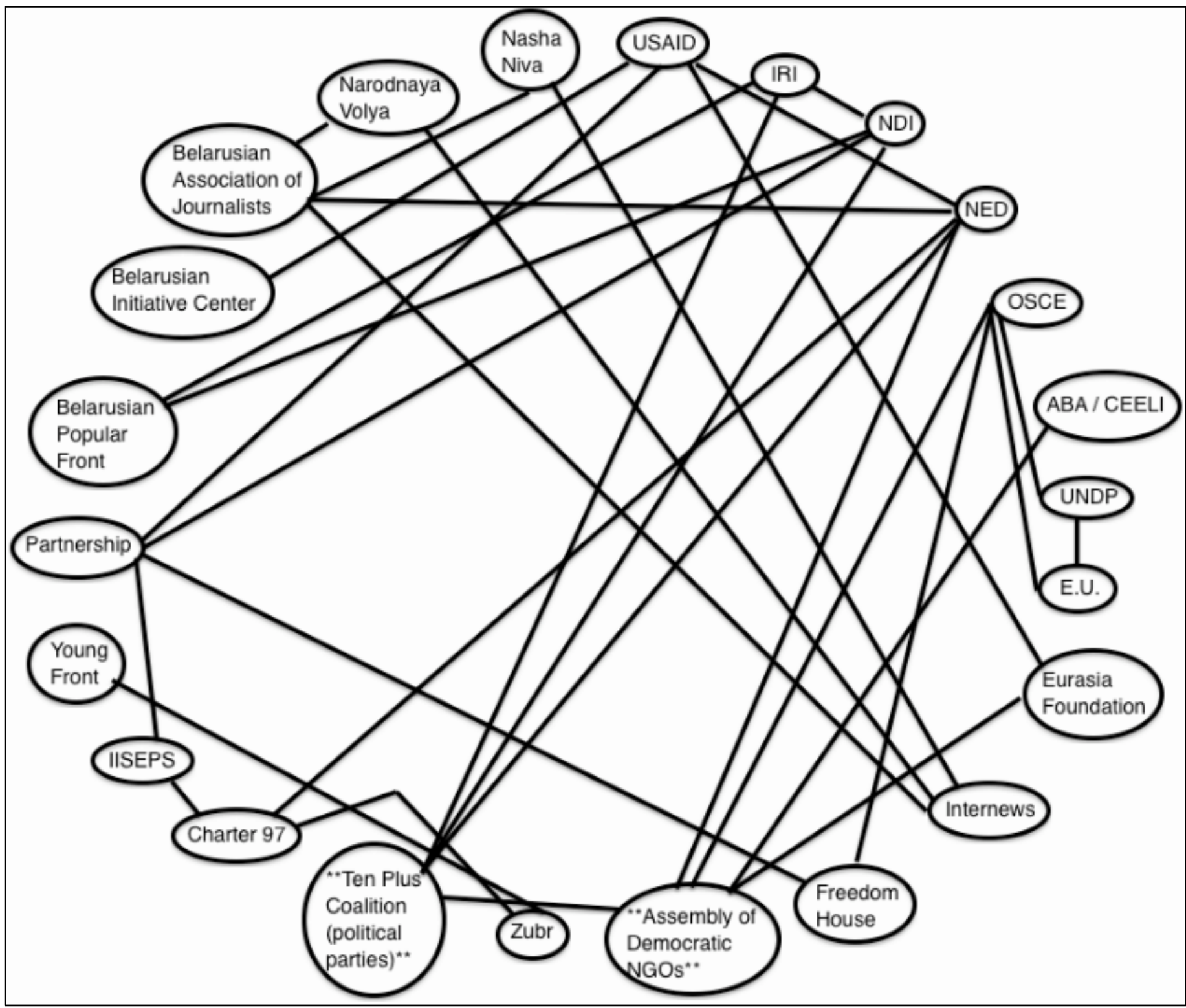

Figure 3: A web almost wholly illustrating the interconnectivity of this network. Note that the transnational connections are fewer and weaker than in previous cases. (graphic created by author)

advice of NDI workers, united in the "Ten Plus Coalition, a group of democratic parties and civic organizations."103 The Coalition's Congress of Democratic Forces in October 2005 nominated a

103 “NDI Annual Report.” National Democratic Institute (2005). www.ndi.org/files/2219_ndi_annual_report_120105.pdf. 
presidential candidate, Alexander Milinkevich, to represent the united opposition. The Office for a Democratic Belarus, the Belarusian Association of Journalists, and several other organizations joined in the Assembly of Democratic NGOs to promote the development of civil society. Such associations certainly multiplied the efficacy of the opposition network. The combined efforts of these sub-networks, for instance, "raised the nationwide name recognition of [Milinkevich] from $5 \%$ before the [nominating congress in October] to nearly $100 \%$ just prior to the elections." 104

Government pressure, nevertheless, was unrelenting. Several NGOs and parties were forced to close or to reduce operations drastically due to pressure from the government. Most notably, the Independent Institute for Socio-Economic and Political Studies (IISEPS) and the NGO Partnership were incapacitated during the election season. IISEPS, a polling agency aiming to "promote civil society and free market economy in Belarus," court order in early 2005 that revoked their license for conducting polls. Partnership was Belarus's only domestic election-monitoring group; several of its principals were arrested a month before the election on, among other indictments, charges of terrorism. Video of the leaders' confession to their crimes was publicized days before the election. ${ }^{106}$ Thus were two important elements of previous color revolutions, polling and election monitors, severely undermined. Indeed, the entirety of the opposition - independent media, political parties, and NGOs (all of which were so vital to color movements in previous cases) - were squeezed by official and unofficial state pressures in the months ahead of the elections, so that opposition activity was severely restricted by March 2006 .

\footnotetext{
104 "FY 2006 U.S. Assistance to the Eurasia: Belarus." U.S. Department of State.

${ }^{105}$ Degutis, Algirdas. “About Us.” IISEPS, An Independent Institute of Socio-Economic and Politycal Studies. http://www.iiseps.org/eabout.html.

${ }^{106}$ Kalinovski Square, Khashchavatski.
} 
Finally, Lukashenko utilized state resources throughout the last weeks before to his greatest advantage. While impeding Milinkevich's travel throughout the country, Lukashenko continued his most longstanding campaign tool: symbolic politics. ${ }^{107}$ State television portrays Lukashenko as a dynamic figure, and conveys "the impression of a very personal supervision of society." 108 He is shown playing hockey, attending a ceremony of the nation's gas industry, driving a large truck on a farm, inspecting a mining operation, and meeting with world leaders. ${ }^{109}$ Milinkevich, by comparison, received practically no coverage by national media aside from a brief speech at the registration of presidential candidates ceremony.

The 2006 presidential election figured to be just another pretense to shore up Lukashenko’s “democratic” regime.

Network Activity During the Denim Revolution

No opposition media outlets covered the election. Government forces prevented independent newspapers from issuing copies, "web pages were shut down, and the independent news agency Belapan also ran into difficulties."110 State television proclaimed victory for Lukashenko and warned of possible attempts by the opposition to overthrow the government.

The reported figures held that Lukashenko had received 83 percent of votes, Milinkevich 6.1 percent, Haidukevich (a pro-Lukashenko candidate) 3.5 percent, and Kazulin (an opposition candidate aligned with Milikevich's supporters) 2.2 percent. The U.S., E.U., and OSCE all declared the elections illegitimate; Russian monitors criticized the West for prejudging the nature of the elections, and deemed the process free and fair. Responding to vague calls by opposition leaders before and early on Election Day, several thousand Minsk residents gathered in October

\footnotetext{
${ }^{107}$ Marples, David. “Color revolutions: The Belarus case.” Communist and Post-Communist Studies 39 (2006): 356.

108 Ibid.

${ }^{109}$ Kalinovski Square, Khashchavatski.

${ }^{110}$ Marples, David. "The Belarus case": 358.
} 
Square to protest the results. Few of the protesters claimed victory for Milinkevich; rather, they claimed that Lukashenko's percentage was impossibly high, citing "non-governmental polls, such as those conducted by Manayev [a sociologist with the IISEPS], indicate that support for the president at the time of the election was around or over $50 \%$." 111

It remains unclear exactly how the electoral fraud was perpetrated. A documentary about the Denim Revolution, Kalinovski Square, briefly explained that a poll in one town (Maloye Sitna) supported Milinkevich at 70 percent; the official results recorded 95 percent of the town's votes for Lukashenko. ${ }^{112}$

In any case, upwards of 20,000 had gathered in October Square by late election night to decry the clearly fraudulent vote count, "despite KGB threats to charge protesters with terrorism and press for the death penalty." 113 Members of Zubr and Young Front - many of whom witnessed the Orange Revolution sixteen months earlier - organized the demonstration, erection of a tent city, and occupation of the square. However, there was "little in the way of planning or coordination between civil society radicals and opposition leaders."114

The number of protesters diminished in the following days. No signs of dissention within the regime or state-controlled media appeared as in previous cases. Indeed, the media's limited coverage of the protest was consistently defamatory and scathing. State security forces arrested anyone attempting to exit or enter the square and intercepted all food and provisions brought for the demonstrators. Groups of Lukashenko supporters were deployed as counterdemonstrators and agitators. Finally, when the number of protesters had dwindled to a few hundred on 24 March, riot police stormed the square, arrested the 328 remaining occupants, and dismantled the

\footnotetext{
${ }^{111}$ Ibid: 361.

${ }^{112}$ Kalinovski Square, Khashchavatski.

113 Silitski, "Belarus": 145.

114 Ibid: 146.
} 
tent city. ${ }^{115}$ The next day, Alexander Kazulin led several thousand (between 5,000 and 20,000) in a march back to October Square, but a wall of riot officers blocked the way. The march instead moved towards the detention facility on Okrestina Street, where many of the detained protesters were supposedly being held. The police dispersed the march in "a bloody melee that left thousands beaten up, several of them in grave condition, tear-gassed, stunned with percussion grenades and chased all over town by club-wielding policemen."116 The only tangible result of the Denim Revolution movement was an eight-day delay in Lukashenko's reinauguration ceremony.

\section{Effect of Transnational Networks of Support in the Denim Revolution}

Most of the keys to successful color revolutions were missing in Belarus and the Denim Revolution movement. Lukashenko is an unconstrained autocrat; he is fairly popular (over 50 percent approval in almost any poll); the regime's security apparatus is united behind him; and the mobilizing ability of the opposition was severely encumbered by government harassment and suppression.

Although there were no exit polls or parallel vote tabulations, the opposition did not contend that their candidate(s) had received more votes than Lukashenko. An IISEPS poll weeks after the election approximated the real results at 63 percent for Lukashenko, 20 percent for Milinkevich. ${ }^{117}$ Opposition activity successfully made Milinkevich into a national figure; he never exuded the dynamism of Saakashvili or Yushchenko. For his part, Lukashenko admitted to election falsification, albeit in the opposite direction. In a meeting with Ukrainian journalists, Lukashenko said:

\footnotetext{
${ }^{115}$ Zarakhovich, Yuri. "Belarus: 'They Knocked My Husband Down and Dragged Him Away'." TIME, March 25, 2006.

116 Ibid.

${ }^{117}$ Silitski, "Belarus": 151.
} 
We falsified the last elections, I already told the westerners. 93.5 percent voted for Lukashenko. This is not a European figure, they said. So we made it $86 \ldots$ Before the elections they told us that if our election figures were European, that they would accept our election. We made European figures. But, as you see, they didn't accept them. ${ }^{118}$

The question under circumstances like those in Lukashenko's Belarus is: "can a democratic opposition make any progress by taking part in such a twisted process - one which, moreover, is designed to destroy whatever faith society might have in alternatives to an authoritarian regime? The case of Belarus suggests that the surprising answer is yes."119 Even in the face of harsh authoritarian suppression, a small, insufficiently supported but nevertheless interconnected opposition in a network system can reach elements of society beyond its base of activists, dissidents, and opposition politicians. The surprise is not that the Denim Revolution movement failed, but rather that it occurred at all. The regime was simply not vulnerable to revolution, but the unprecedented public dissent arguably occurred because of the resilience of the opposition network, erected as it was with the help of foreign partners and utilized in March 2006 by its domestic constituents.

\section{Russia - The For Fair Elections movement ${ }^{120}$}

The Russian Federation, representing the largest country and principal heir of the former Soviet Union, became the greatest focus of post-Soviet international aid. Foreign government aid to Russia in the 1990s surpassed \$1 billion per annum; the total influx of private aid most likely approached this figure.

\footnotetext{
${ }^{118}$ BelaPAN - Belorusskoe privatnoe agentstvo novostei. "Lukashenko: Poslednie vybory my sfalsifitsirovali." Belorusskie i mirovye novosti. http://news.tut.by/politics/77777.html. (translated by author).

${ }^{119}$ Silitski, "Belarus": 138.

${ }^{120}$ Also known as, the "snow revolution" (snezhnaya revolyutsiya) or the "white ribbon movement" (belaya lenta dvizheniya).
} 
An explosion of free societal activity characterized Russia during Boris Yeltsin's presidential tenure (1991 - 1999). Yet, besides opening Russia up to foreign donors, agencies, and organizations, the newfound and unchecked freedom resulted in unprecedented corruption. Government officials and unscrupulous "oligarchs" used their influence to enrich themselves with formerly state-owned industries and businesses.

Vladimir Putin's regime, in place since late 1999, has done much to decrease this rampant oligarchical corruption. The reassertion of state predominance under Putin, however, has extended to virtually all sectors of society, not just industry. Since Putin's ascension to the presidency, the government - not always with Putin's public endorsement, though seemingly at his behest - has implemented numerous restrictions on the allocation of foreign aid and the free operation of political and civil society entities. Understandably, various actors and individuals, chafing from these constraints, rallied to Putin's opposition. Yet, among the many disaffected members of Russian society - pensioners, communists yearning for a return to the Soviet system, ethnic minorities, and nationalists to name a few - democrats are just another group of the relatively small, active opponents of Putin's regime.

Nevertheless, the reinvigoration of authoritarian practices in Putin's Russia has triggered substantial opposition activity. From the early 2000s to the middle of President Dmitri Medvedev's ${ }^{121}$ tenure (2010), anywhere from dozens to a few thousand people participated in public demonstrations of opposition to Putin or some facet of his regime. Shortly before the December 2011 parliamentary or "Duma" elections, however, protest activity was epitomized by the actions of Strategy-31 activists. This opposition group, which formed to protest the

\footnotetext{
${ }^{121}$ In what was later admitted as a prearranged management of the position of president, Dmitri Medvedev stood for election in 2008, at the end of Putin's constitutionally limited two consecutive terms. After serving as President Medvedev's prime minister for four years, Putin ran for President again in 2012, reassuming the position of chief executive (though most scholars argue that he exercised its powers through Medvedev from 2008 to 2012) on 7 May 2012.
} 
abridgement of constitutionally-enshrined (in article 31) freedom of assembly, attempted to hold regular protests at Triumfalnaya Ploshchad ("Triumphal Square") in central Moscow on the $31^{\text {st }}$ day of every month with 31 days. Over the course of two hours on 31 October 2011, a few dozen activists shouted slogans and interacted with the scores of journalists while hundreds of riot officers (easily more than four to every activist, journalist, or layperson in the square) patrolled the scene, continually ordered people to vacate the square, and wrestled active protesters from the crowd and escorted them to a chorus of "Pozor! Pozor! Pozor!" ("Shame [on the police]!").

Then, widespread claims of fraud in the 4 December parliamentary elections provoked an impromptu gathering the next day of over 5,000 whistleblowers (many protesters blowing on plastic red whistles), denouncing the electoral falsification. Five days later (on 10 December) a crowd of tens of thousands (between 25,000 and 80,000 depending on whether one inquired with the police or with the protest organizers) assembled on Bolotnaya Ploshchad ("Marshy Square"). The outpouring of opposition was the largest seen in Russia since the collapse of the Soviet Union. It kicked off a sustained campaign by the political opponents of Putin's regime to demand fair elections and protest in the public spaces of Moscow and other Russian cities until that "reasonable demand," among others, was met. Over a year as well as the presidential election (4 March 2012) and inauguration (7 May 2012) have passed and the opposition has achieved no substantive victories in changing the regime. Indeed, Putin's return to the Presidency coincided with a new assault on political opposition and civil society by the Russian government. The opposition movement that began on 4 December 2011 is still limping on as of the beginning of 2013 .

Transnational Networks in Russia before the For Fair Elections Movement 
Color revolutions in bordering countries most definitely provoked a government backlash against potentially revolutionary elements in Russian society. Putin has expressed concern over the movements in a characteristic mocking style:

'What is most dangerous, you know, is the creation of a system of permanent revolution, whether that be "rose" [rosovykh] or some yet-to-be-invented "blue" [golubykh].' In this sentence, he attacked the 'Rose Revolution' on two levels. First, in an attempt at homophobic humor, he played on the Russian slang meanings of 'rose' as lesbian and 'blue' as gay male. Second, he tried to tarnish Georgia's deliberately self-limiting revolution with the notion of 'permanent revolution', which both harked back to Soviet anti-Trotskyite propaganda and evoked memories of Russia's turmoil during the early 1990 s. $^{122}$

While a firmer hand with civil society and "foreign interference" was detected in his first presidential term, Putin oversaw the passage of a seminal piece of legislation in early 2006: the Russian Federation Law, On Introducing Amendments to Certain Legislative Acts of the Russian Federation, more commonly known as the 2006 Russian NGO Law. The shorter, less cryptic title speaks to the target of the legislation. The law "introduced burdensome and difficult-tomeet reporting requirements for NGOs, accompanied by severe penalties for non-compliance; new and similarly burdensome registration procedures for Russian and foreign NGOs operating in Russia; and new broad powers of the registration bodies to audit the activities of NGOs. ${ }^{" 123}$ The pretext of the law came from FSB Director Nikolai Patrushev's May 2005 speech to parliament, where he asserted that foreign agents (explicitly naming IRI and NED) "were using NGOs to undermine Russia's security. ${ }^{124}$ Like with other parts of Russian law, NGOs and opposition groups feared the "selective implementation" practices of government organs; that is,

\footnotetext{
${ }^{122}$ Horvath, Robert. "Putin's 'Preventive Counter-Revolution': Post-Soviet Authoritarianism and the Spectre of Velvet Revolution." Europe-Asia Studies 63, no. 1 (2011): 7.

123 "Russia - NGO Law Monitor." The International Center for Not-for-Profit Law (ICNL). http://www.icnl.org/research/monitor/russia.html

${ }^{124}$ Horvath, "Putin's 'Preventive Counter-Revolution"': 18.
} 
the law would be a tool used to pursue organizations of concern to the government, rather than being applied fairly to all civil society (a daunting prospect on its own). The application of this and other Russian laws - especially the Law on Public Associations, the 2002 Law on Countering Extremist Activity, and certain articles of the Criminal Code, like articles 280 and $282^{125}$ - shrank the number of NGOs from over 600,000 to just $220,000 .^{126}$

Within this hostile environment, an enlarged but familiar (USAID, NDI, IRI, NED, E.U., Soros's Open Society Foundation, Internews-Russia, and so on) group of foreign organizations, agencies, and governments provided regular assistance to squeezed sectors of Russian society. Millions of dollars flowed from foreign organizations and governments to Russian grantees. In 2010 alone, George Soros's Foundation dispensed over \$6 million to a dozen Russian organizations. $^{127} \mathrm{NED}$, supported by USAID, provided $\$ 4.15$ million in the form of 74 grants, including $\$ 71,242$ for election polling by the Levada Center, $\$ 46,902$ for the development of the East European Democratic Center's “crossborder network of civil society organizations," $\$ 80,000$ for AGORA's legal defense initiative, and $\$ 325,961$ over seven project grants to branches of Society "Memorial.", 128

Some of the most notable Russian opposition beneficiaries of the transnational network are:

\section{Notable Russian actors:}

Solidarity (Solidarnost), liberal democratic party coalition

Strategy-31, activist group

Yabloko ("apple"), political party

People's Democratic Union, political party

Golos ("voice"), election monitoring group

\footnotetext{
125 280: Public Appeals for a Forcible Change of the Constitutional System of the Russian Federation; 282: Incitement of National, Racial, or Religious Enmity; "Section X." The Criminal Code Of The Russian Federation. http://www.russian-criminal-code.com/PartII/SectionX/Chapter29.html.

126 "Russia - NGO Law Monitor." The International Center for Not-for-Profit Law (ICNL).

127 "2010 Expenditures." Open Society. N.p., n.d. Web. 19 Sept. 2012. <c14989882.r82.cf2.rackcdn.com/pdfs/osfexpenditures-2010.pdf $>$.

128 "Russia." National Endowment for Democracy. http://www.ned.org/node/233.
} 
Dozhd ("rain") television channel

Society "Memorial," a human rights and historical truth organization

The Other Russia, a political party coalition

Carnegie Moscow Center, think tank

AGORA, human rights watchdog group

Levada Center, polling and sociological research institute

The Khimki Forest Defense Movement, environmental activist group

Echo of Moscow, radio station

A Just Russia, political party

Novaya Gazetta ("New Gazette"), newspaper

In recent years opponents of the Putin regime have made several attempts to formalize domestic sub-networks and create greater unity. A slew of untenable party coalitions and conventions like 2004's All-Russian Civic Congress endeavored to create deep, resilient, and longstanding bonds of opposition unity. The vast ideological disparities between opposition forces, however, hindered the establishment of sustainable coalitions. Furthermore, Russia's opposition consists of several influential leaders, each with their own base of support. This reality constituted a major obstacle to opposition unity; the For Fair Elections movement would reconnoiter this problem and only manage to create a system that froze the parity of opposition leaders' popularity.

Though not fully seized upon, the array of political parties, non-governmental organizations, and international sources of support was vast. The Putin government, unlike any other cases, went beyond simple authoritarian methods of cowing the opposition; it developed several proactive, ostensibly non-governmental means of disrupting or countering opposition activity.

Gleb Pavlovskii, advisor to the Kremlin, pioneered new defenses against color movement opposition. He asserted, "The most important thing to avoid was a passive, defensive posture." 129 Accordingly, a network of counter-revolutionary groups was created. The most

\footnotetext{
${ }^{129}$ Horvath, "Putin's 'Preventive Counter-Revolution"': 15.
} 
well-known element of this apparatus is the pro-Putin youth group, Nashi (meaning "Ours"). It was created on the model of Otpur and Kmara, but for the purpose of bolstering rather than opposing the regime. Since its formation in 2005, detachments of Nashi members frequently stalked and harassed opposition demonstrations, practically unchecked by the police no matter what their provocative action.

The government also utilizes state-owned or aligned polling and media sources to undermine opposition activity. Critics often lambast the All-Russian Center for the Study of Public Opinion, or VTsIOM for manipulation of polling and surveys in favor of the Putin regime. Citizen Watch, an election monitoring NGO with ties to the government, acts as a progovernment mirror to Golos. Media outlets too form part of the governments network; NTV, for example, habitually conducts "investigative reports" aimed at exposing the purportedly corrupt and seditious practices of opposition parties, leaders, and organizations. NTV functions with a fair degree of impunity and rarely falls prey to Russia's harsh libel laws (though their conduct, by many accounts, often qualifies as libelous).

In spite of the various and extensive tactics employed to stifle and disrupt, the opposition to Putin's regime persevered. Indeed, pervasive decline in the popularity of ruling party United Russia gave hope to the opposition. Levada Center polls indicated diminished approval of United Russia and consistent doubt regarding the veracity of elections (see Appendix I). The December 2011 parliamentary vote represented a significant opportunity for anti-Putin forces, but little confidence could reasonably exist that any mass outburst of dissent would occur following the vote, whether it was falsified or not.

Network Activity During the For Fair Elections movement 
Examining the course of events from 4 December 2011 to 7 May 2012 and beyond requires one to contend with the distinctively non- (or even anti-) color revolution atmosphere of early protests. Golos tracked the conduct of the elections throughout the country via a series of volunteer monitors and live video streams of polling places. An online mapping application developed in part with USAID and NED funds - that differentiated between many types of electoral fraud made access to accounts of the vote's fairness available to everyone with an internet connection. In all, Golos recorded 7,801 cases of fraudulent activity. ${ }^{130}$ The official figures, which were already underwhelming for United Russia as it signaled the loss of the legislative super majority that they had held since 2003 and was consistent with diminishing popularity in local elections, were further palled for the party of power by widespread incidents of fraud: ${ }^{131}$

- United Russia: 49.31 percent

- Communist Party: 19.19 percent

- A Just Russia: 13.25 percent

- Liberal-Democratic Party: 11.68 percent

Perhaps the domestic entity most disposed to a network system (boasting strong ties both to international partners like USAID, NED, OSCE, and the Open Society Foundation, and to domestic actors like Society "Memorial" and the Sakharov Centre), Golos was able to withstand intense pressure from the regime before and after the election period. Cyber-attacks, government raids, harassment by NTV, Nashi demonstrations outside their office, and fines number among the assault tactics employed by the regime. Despite these hindrances, Golos fielded a few thousand official election monitors (and utilized supplementary volunteers and distance observation methods) during the parliamentary vote. A statement the day after the elections

\footnotetext{
130 "Vybory 4 marta 2011 goda | Vce soobshchehiya." GOLOS - Karta narushenii na vyborakh. www.kartanarusheniy.org/2011-12-04.

131 "Svedeniya o provodyashikhsya vyborakh i referendumakh." Centralnoi izbratelnoi comissii Rossiyskoi Federatsii.
} 
announced preliminary findings: support for United Russia was inflated throughout the country, especially in the Caucus regions (such as the Chechen Republic which recorded 99.5 percent for United Russia) and in the districts of Moscow (with wild variation between districts, indicative of vote tampering). ${ }^{132}$ Subsequent reports confirmed these findings and questioned United Russia's already subpar performance.

While these reports fueled opposition outrage, the protest movement that thereafter coalesced under the banner of "For Fair Elections" did not adopt a revolutionary posture. Speeches at December's protests often declared that the objective was fair elections, not revolution. Indeed, the rhetorical moderation in calls to action often strained to declare, perhaps for the benefit of the ubiquitous forces of the interior ministry, that this was not a color movement. This stance might have resulted from two related polling concerns. First, while some speculation amongst independent polling agencies and protesters placed United Russia's total percentage of the vote in the low 30 s, sometimes even in second place to the communists, clearly either United Russia or the Communist Party (typically in agreement with the ruling United Russia) had won the election. Second, the level of Putin's popularity had not matched the plummeting of United Russia's support. Over half the country still approved of Putin, and thus no mandate for regime change existed on any front. Yet the tens of thousands that gathered on Bolotnaya Square a week after chanted slogans like "Russia without Putin!," "Russia will be free!," "we have the power!," and so on. Hints of a more radical tenor appeared from the likes of Alexei Navalny (a lawyer and anti-corruption blogger with the largest support base of opposition

\footnotetext{
132 “Kratkoe zayavlenie assotsiatsii «GOLOS» po itogam vyborov 4 dekabrya 2011 — Assotsiatsiya «GOLOS»." Glavnoe - Assotsiatsiya «GOLOS». http://www.golos.org/news/4535.
} 
leaders), who said proclaimed to the nearly 100,000 assembled on Sakharov Avenue on 24 December: "We are peaceful people, but we cannot suffer endlessly.",133

Through the first two months after elections, the For Fair Elections movement made no visible progress on achieving its main objectives, which, though sometimes obfuscated by the many voices of the oppositions leadership, can be said to include the annulment of the 4 December election results, a new vote conducted freely and fairly, and the resignation and investigation of Central Election Commission Chairman Vladimir Churov.

The first major demonstration after the long Russian holidays was held on 4 February 2012, a march from Kaluzhskaya Square to a rally on Bolotnaya. Braving subzero temperatures, well over 100,000 people turned out to denounce the Putin regime and the parliamentary elections. Stamping their feet and rubbing their hands (or in extreme cases, going to the warming tent at the opposite end of the square), the assembly listened to speeches and musical performances. Late Soviet anthems of dissent such as Viktor Tsoi's song "Peremen" ("Change”) and live performances from the likes of Yuri Shevchuk harked back to the dissent of the late 1980s and early 1990s.

The 4 February rally also witnessed the elaboration of a fiercely nationalist message. State-owned media and government officials had denounced or dismissed the nascent democratic movement as an instrument of Western intervention in Russia's internal affairs - a common charge, and one to which Russians seem to be particularly sensitive. The response of several opposition figures was to deny the claim, assert their distaste for America, and allege Putin's collusion with the U.S. Left Front leader Sergei Udaltsov typified this development:

[Government counterdemonstrations] accuse us, alleging that we are acting on the interests of the USA, that we want to split up Russia. But, I am here saying it's lies and provocation; lies, $\mathrm{b}^{* * * * * * *}$, and provocation! Excuse me for the coarse

\footnotetext{
${ }^{133}$ Observed and translated by author.
} 
word. In 1999, when America bombed Yugoslavia, I was by the embassy, there throwing $\mathrm{s}^{* * *}$ at the American embassy with everyone...But where was Putin then? Where were you? Where was Medvedev? ... That's who works in the interests of America. ${ }^{134}$

Whereas Western support constituted almost a point of pride in Georgia and Ukraine, the existence of U.S.-assisted opposition elements was shameful to several major leaders of the For Fair Elections movement, who perhaps feared the general public's supposed antipathy to American elements in Russia. While the West disapproved of the conduct of Russia's elections, the comments of Udaltsov and others surely did not elicit the kind of diplomatic pressure that bolstered Yushchenko and Our Ukraine.

For Fair Elections leaders were denied a permit to demonstrate once more before the 4 March presidential election, so they organized an event called "White Circle." On 26 February, as many as 40,000 people ${ }^{135}$ lined Moscow's Garden Ring Road, festooned with white ribbons, holding white balloons, and

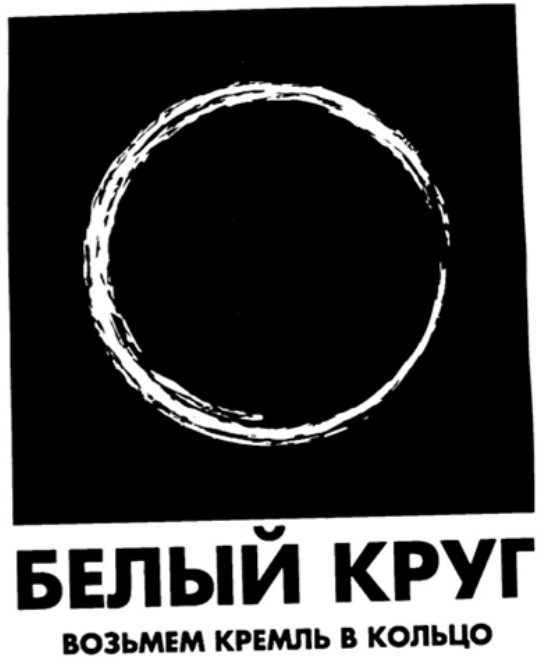

26 ФЕВРАЛЯ В 14:00

ДВИЖЕНИЕ ЗА ЧЕСТНЫЕ ВЫБОРЫ СЛЕДУЮщИЙ ЩАГ

waving white flags and flowers. Opposition leaders were interspersed along the ring; sympathetic motorists drove around the 10-mile loop, holding flags out their windows and

Leaflet announcing the "White Circle" demonstration on the Garden Ring Road (picture by author)

\footnotetext{
${ }^{134}$ Observed and translated by author.

${ }^{135}$ Radia, Kirit. "Russians Protest Putin in 'Big White Circle' - ABC News." ABCNews.com. http://abcnews.go.com/blogs/headlines/2012/02/russians-protest-putin-in-big-white-circle/.
} 
honking in support (or else because the protest was causing several traffic jams); and, groups of pro-government youth activists deployed at several points along the road and wore signs that said "Putin loves all” or “one week until Putin's victory”.

The Presidential election was held on 4 March. No major protest was scheduled for that evening, but the anticipation of more fraud led opposition leaders to prepare for a rally the following night. Official results and state media heralded a clear, decisive, and legitimate victory for Vladimir Putin: ${ }^{136}$

- Vladimir V. Putin: 63.6 percent

- Gennady A. Zyuganov (Communist Party): 17.18 percent

- Mikhail D. Prokhorov: 7.98 percent

- Vladimir V. Zhirinovsky: 6.22 percent

- $\quad$ Sergei M. Mironov: 3.85 percent

While few if any doubted that Putin legitimately won at minimum an overwhelming plurality, Golos did monitor claims of fraud, registering 5,229 instances on its website. Irregularities were concentrated in cities (especially Moscow and St. Petersburg) and in southern Russia, where places like Rostov region reported 146 percent turnout. Such comical signs of fraud provided fodder for subsequent protests: "Elections cannot be fair when all $146 \%$ don't vote" read one woman's sign at a rally on 10 March. ${ }^{137}$ A teary-eyed victory speech by President-elect Putin similarly provoked the ire of opposition protesters: "Moscow does not believe in tears" (referencing a movie from the late Soviet period) appeared on several placards at the 5 March demonstration.

\footnotetext{
136 “Svedeniya o provodyashikhsya vyborakh i referendumakh.” Centralnoi izbratelnoi comissii Rossiyskoi Federatsii.

http://www.vybory.izbirkom.ru/region/region/izbirkom?action=show\&root=1\&tvd=100100031793509\&vrn=10010 0031793505®ion=0\&global=1\&sub_region=0\&prver=0\&pronetvd=null\&vibid=100100031793509\&type=226.

${ }^{137}$ Observed and translated by author.
} 
The rallies on 5 and 10 March involved "crowds of just 10,000 to 25,000, ,"138 signaling to some that the fervor of dissent was waning. Violent action by riot officers at the end of the 5 March event on Pushkin Square, moreover, did not bode well for the opposition. Hundreds were arrested - including Sergei Udaltsov, Alexei Navalny, and Ilya Yashin - in that melee on the pretext that they violated the terms of their assembly permit and did not vacate the Square by nine o'clock.

To be sure, the loose alliance enshrined in the For Fair Elections movement, already fraying by some accounts, had one last seminal event to plan around: the Presidential inauguration on 7 May 2012. Udaltsov, on behalf of the movement, obtained a permit once again to march from Kaluzhskaya Square to Bolotnaya and hold a rally there on 6 May. The week before the demonstration witnessed a massive influx - hundreds of thousands - of additional interior troops and riot officers as well as detachments of the specialized ODON division (a unit of the Interior Ministry).

In the early hours of the afternoon, between 25,000 and 40,000 exited the Oktyabrskaya metro station and assembled on the broad thoroughfare north of Kaluzhskaya Square. After waves of protesters - principally under the direction of Udaltsov and Left Front activists situated themselves behind several banners endorsing the ouster of Putin, the two kilometer march began. At the end of that road just beyond the entrance to Bolotnaya stood three lines, each a few men deep, of interior ministry troops and riot officers. Behind these lines were tight formations of service vehicles, troop carriers, buses, and windowless Black Marias.

When the main body of the march neared Bolotnaya, a line of troops blocked their access via the western bridge. Some protesters crossed a footbridge to the east, but most remained on

\footnotetext{
${ }^{138}$ Wolchik, Sharon L.. "Putinism Under Siege: Can There Be a Color Revolution?." Journal of Democracy 23, no. 3 (2012): 63 .
} 
the boulevard. Groups began attempting to push through the police lines and march on the Kremlin. It remains unclear what role opposition leaders played in attempting to march to Red Square. For his part, Udaltsov was on the eastern end of Bolotnaya Square (having crossed the footbridge) when clashes began. Speaking from the previously constructed dais, he encouraged the hundreds gathered on the square to join the rest of the demonstrators in occupying the area. While delivering this announcement, Udaltsov was taken under arrest by several police officers and rushed away from the square to the northeast. Alexei Navalny and Boris Nemtsov were captured and evacuated in the same manner.

Violent altercations between riot officers and protesters continued into the evening. Protesters pelted troops with bottles, debris, and a few Molotov cocktails. Roving groups of riot officers penetrated the ranks of the demonstrators and seized aggressive individuals. Slowly, after dozens of police and protester injuries and several hundred arrests, the demonstrators dispersed, trudging back toward the Oktyabrskaya metro station.

The next day, opposition activists were driven away from the route of Putin's inaugural convoy. As President Putin took the oath of office, bands of a few thousand protesters, police forces, and pro-government youth groups played an extended cat-and-mouse game on the streets of the city center. A youthful group of protesters headed southward on Nikitskiy Boulevard in an attempt to approach the Kremlin via Noviy Arbat, but found their path blocked by a wall of riot troops. They wheeled round and headed north to Pushkin Square (and supposedly from there down to the Kremlin via Tverskaya Street). Nashi activists delayed them at the southern end of the Tverskaya Boulevard Park. After a half-hour march, during which troop carriers sped passed, the march met a line of police opposite from Pushkin Square. The officers dispersed the 
march, drove back the demonstrators, and detained scores. Various news reports describe similar events around the city.

Back in the President's office, Putin wasted little time; new restrictions on NGO activity and public assemblies passed during his first months in office, including drastic increases in fines for unsanctioned protests (a sixty-fold increase for culpable individuals, and forty-fold for organizations) and a bill requiring domestic NGOs in receipt of foreign grants or monies to carry the label "foreign agent," a moniker with adverse Soviet connotations. ${ }^{139}$ Among the myriad other recent government actions designed to restrict opposition network activity, the Kremlin demanded the evacuation of USAID from Russia in late September 2012. Even if some of its operations are conducted in absentia, the expulsion of the U.S. government's largest conduit of foreign aid raises existential concerns for the already weak transnational opposition network, as it is currently constituted.

\section{Effect of Transnational Networks of Support in the For Fair Elections movement}

In the five-month period between State Duma elections, the presidential election, and Putin's inauguration, demonstrations and public displays of civic unrest "took place in 96 cities across the country." 140 An almost inestimable number of international and domestic actors with a correspondingly high diversity of motivations, methods, and goals - contributed to the swell of anti-government activism. The For Fair Elections movement of Moscow and other major cities was perhaps the most prominent of these opposition exertions.

Like other color movements, For Fair Elections fought governmental tampering with the citizenry's electoral rights. In all likelihood (as in Belarus in 2006), a free and fair vote would not affect the outcome of Russia's presidential vote, merely the margin by which Putin secured

\footnotetext{
${ }^{139}$ Russia - NGO Law Monitor." The International Center for Not-for-Profit Law (ICNL).

${ }^{140}$ Wolchik, Sharon L.. "Putinism Under Siege": 63.
} 
victory, nor would legitimate elections greatly altar the nature of the Duma. Thus, the opposition's struggle was one of principal and not of practical reality.

Unlike other cases, Russia's opposition did not fully exploit the resources possessed by its transnational network of support. Some domestic actors worked with Western partners while others abhorred the thought. Such wide divergence of opinion and position typified the For Fair Elections movement and resulted in loose affiliations and tenuous bonds uncharacteristic of effective transnational networks.

Furthermore, the concept of one alliance uniting several distinct communist, socialist, democratic, and fascistic nationalist factions and interests is laughably unsustainable. It would surely test the bonds of a sturdy network system, and quickly unravel weaker associations (as it did in Russia). Indeed, given the ideological disparity among the For Fair Elections coalition, it is a wonder that more groups did not mimic Society "Memorial" and refuse to join the movement, citing the futility of aligning with parties that hold virtually no other (besides distaste for the Putin regime) values in common. ${ }^{141}$ This fundamental weakness speaks to the necessity of unifying values to bind a transnational network. In Russia, while leaders like Garry Kasparov and Boris Nemtsov called for liberal democratic regimes modeled on the West, several of their partners in opposition were championing profoundly different political realignments: Sergei Uldatsov calling for a return to a Soviet system, Vladimir Tor advocating a radically nationalist regime, and so on.

Most importantly, the opposition network faced a regime with the most sophisticated repression and counterrevolutionary measures yet encountered in the post-Soviet space. Studious observation of and experience with color revolutions in adjacent countries effectively

\footnotetext{
${ }^{141}$ See. Memorial Human Rights Group. "O granitsakh sotrudnichestva. Zayavlenie «Moscovskovo Memoriala»." Memorial Pravozashita. www.memo.ru/d/3148.html (accessed March 28, 2012).
} 
inoculated Russia against the "democracy virus." The efficacy of the pro-government network Nashi, NTV, VTsIOM, etc. - attests to the strength of networks of support.

In the absence of a fully developed transnational network of support, the opposition still achieved unprecedented mass mobilization and clearly engendered concerns among the top rungs of state authority. This fact should prompt concerns within the Putin regime of the potential power of the opposition if those comprehensive network methods are employed. The swift restrictive actions of the reinstated President Putin indicate an understanding of the opposition's capacity to agitate for change.

\section{Assessing Transnational Networks in Color Movements}

Placing the potential causal factors - including the presence of transnational networks, the strength of existing networks, and the degree of authoritarian backlash - in a "truth table"142 creates a precise structure to test the role of observed variables in the sociopolitical phenomena of color revolutions.

Table 1 presents possible elements of successful color revolutions. Therein, A resilient interconnected web of independent media outlets, NGOs and political parties, and foreign donor organizations agencies constitutes a "strong network." "Significant authoritarian backlash" corresponds to the implementation of a restrictive legal framework that hinders transnational network activity as well as the exercise of governmental and extra-governmental means of opposition harassment and suppression.

\footnotetext{
${ }^{142}$ See: Ragin, The Comparative Method...
} 


\begin{tabular}{|l|l|l|l|l|l|l|l|l|}
\hline Case & $\begin{array}{l}\text { Successful } \\
\text { color } \\
\text { revolution } \\
?\end{array}$ & $\begin{array}{l}\text { Transnational } \\
\text { network(s) } \\
\text { present? }\end{array}$ & $\begin{array}{l}\text { Strong } \\
\text { network? }\end{array}$ & $\begin{array}{l}\text { Significant } \\
\text { authoritarian } \\
\text { backlash? }\end{array}$ & $\begin{array}{l}\text { Semi- } \\
\text { autocratic? }\end{array}$ & $\begin{array}{l}\text { Division } \\
\text { among } \\
\text { regime's } \\
\text { coercive } \\
\text { forces? }\end{array}$ & $\begin{array}{l}\text { United } \\
\text { opposition? }\end{array}$ & $\begin{array}{l}\text { Unpopular } \\
\text { incumbent? }\end{array}$ \\
\hline $\begin{array}{l}\text { Georgia } \\
2003- \\
04\end{array}$ & Yes & Yes & Yes & No & Yes & Yes & Yes & Yes \\
\hline $\begin{array}{l}\text { Ukraine } \\
\text { 05- }\end{array}$ & Yes & Yes & Yes & No & Yes & Yes & Yes & Yes \\
\hline $\begin{array}{l}\text { Belarus } \\
2006\end{array}$ & No & Yes & No & Yes & No & No & Yes & No \\
\hline $\begin{array}{l}\text { Russia } \\
2011- \\
12\end{array}$ & No & Yes & No & Yes & Yes & No & No & No \\
\hline
\end{tabular}

Table 1: A truth table of potential causal variables of color revolutions in the examined cases. (created by author)

As the table shows, the presence of a strong transnational network is positively correlated with successful color revolution. Conversely, significant authoritarian backlash - such as the restrictive laws and state harassment in Belarus, and the moderate legal harassment and persistent agitation of pro-government networks in Russia - is inversely related to color revolution.

Other variables may contribute to the capacity of a color movement to achieve regime change. The presence of a central, unifying revolutionary figure is surely a significant factor. Saakashvili and especially Yushchenko were vital to their movements, whereas Milinkevich was fairly obscure before the 2005-06 presidential campaign in Belarus, and Russia's opposition contained numerous influential figures without one of paramount importance. The timing and nature of election cycles may also represent a weighty condition. Belarus's presidential election was not preceded by parliamentary elections; furthermore, Election Day was scheduled for 19 March possibly to discourage would be protesters from demonstrating in freezing temperatures. Nevertheless, these and other conditions and factors are probably of ancillary importance. 
In so far as their unfettered operation bolsters and fundamentally contributes to the strength and skill of crucial opposition sectors - election monitors and pollsters, independent media, mobilizing groups, and political parties - transnational networks constitute an integral element of a successful color revolution movement. Cooperation within a strong, if perhaps informal network system acts as a sustainable multiplier of opposition resources and potency. Conversely, weak networks may deliver surprising results, but simply cannot be sustained effectively over long periods.

The case of Russia's For Fair Elections movement demonstrates the essential fact that transnational advocacy networks are necessarily value-driven. The absence of a core of unifying values handicaps the formation of a resilient and interconnected web of organizations, agencies, and political parties. Vast ideological incongruence among the For Fair Elections movement prevented it from congealing into anything more sturdy and robust than a loose association with a common enemy.

The dynamic of a strong network faced with significant authoritarian backlash (unobserved in the four cases presented in this paper) undoubtedly would clarify the extent of a transnational networks' decisiveness in color revolution movements. This eventuality, however, is unlikely due to the reciprocal nature of opposition networks and governing regimes. In other words, a sufficiently liberal sociopolitical environment, which allows for transnational network development, is incompatible with an authoritative governmental system capable of generating substantial and persistent measures of network suppression.

The potentially decisive role (along with other revolutionary characteristics) of transnational democratic networks in precipitating and effectively navigating color revolutions has not escaped the notice of other (semi-) authoritarian regimes in the post-Soviet space (and 
beyond). In the wake of revolutions in Serbia, Georgia, and Ukraine, a trend of so-called "authoritarian backlash" spread throughout the hitherto unchallenged authoritarian states in Eastern Europe and Eurasia. Innovative and sweeping measures that empowered coercive forces to harass incessantly and that created parallel networks to cow the opposition using a system that mirrored their organizational strength. With a set of well-developed tools, specifically counterrevolutionary mechanisms and (or at least) an unwavering coercive apparatus, authoritarian regimes have neutralized transnational democratic networks and forestalled wouldbe color revolutions. Thus, successful color revolution is highly unlikely in cases without the intra-regime preconditions, no matter the strength of an opposition network (although, an internally secure regime typically produces a correspondingly weak opposition).

A well-established transnational democratic network represents one essential factor in winning color revolution movements. 


\section{Appendix I}

Levada Center polling regarding United Russia and elections: ${ }^{143}$

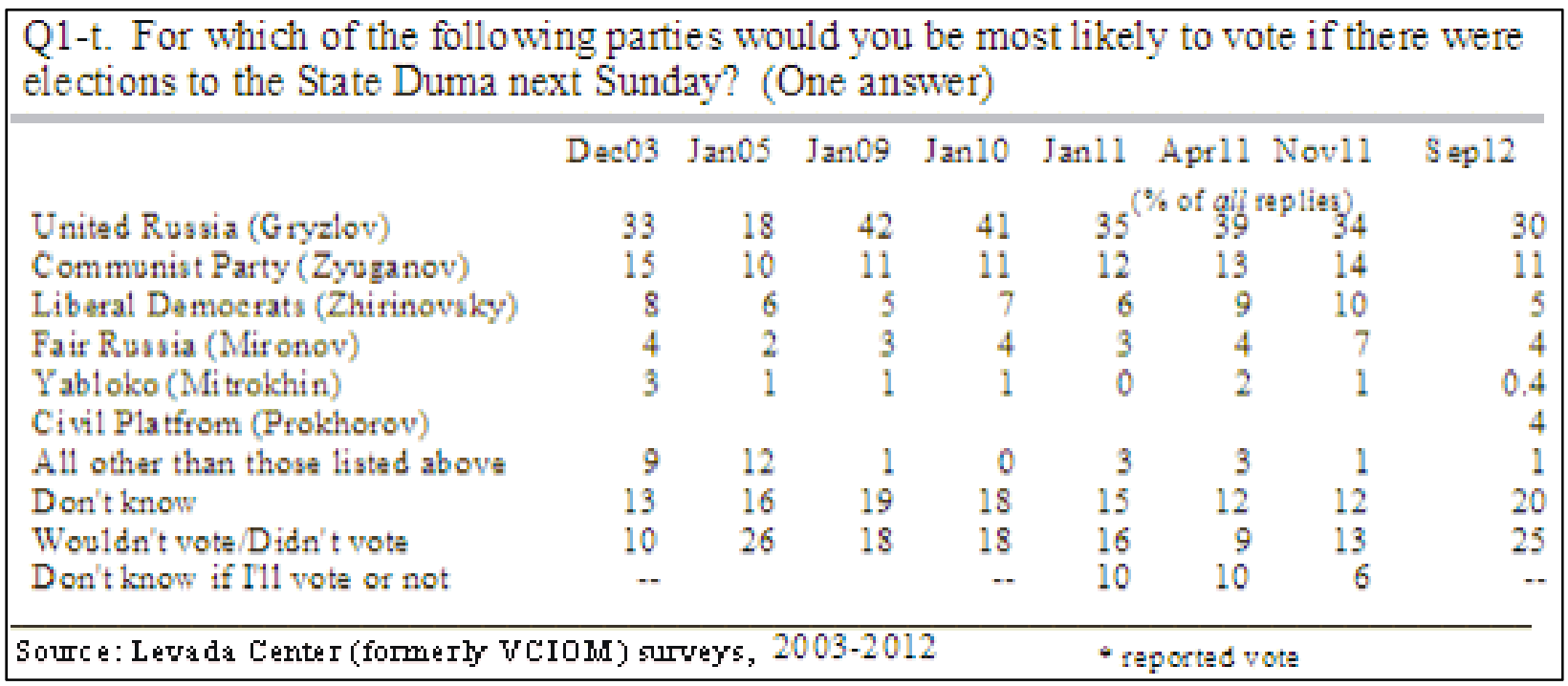

Q1-t. Do you think that elections to the State Duma this year will be on the whole conducted according law and honest, or do you think they will be dirty (marred by slander, pressure on voters and machinations with ballot papers, etc.)?

\begin{tabular}{|c|c|c|c|c|c|c|}
\hline & Oct 03 & Ju1.07 & Sep.07 & $\begin{array}{l}\text { Oct- } 07 \\
\text { (percent }\end{array}$ & Aug-11 & Nov-11 \\
\hline Completely honest & & 3 & 3 & 13 & 4 & \\
\hline Mostly honest & & 26 & 28 & 22 & 34 & \\
\hline Total honest & 21 & 29 & 31 & 35 & 38 & 37 \\
\hline Manipulated & & 44 & 37 & 39 & 38 & \\
\hline Completelym anipulated & & 14 & 20 & 9 & 11 & \\
\hline Total manipulated & 57 & 58 & 57 & 48 & 49 & $\overline{4} 2$ \\
\hline Don't know & 23 & 13 & 12 & 17 & 14 & 21 \\
\hline
\end{tabular}

143 "Russia Votes." Centre for the Study of Public Policy - University of Strathclyde. http://www.russiavotes.org/duma/duma_vote_trends.php\#008. 
Q6b-t. In which party's interests do you think the election will be manipulated?

Source : Levada Center, nationw ide surveys, 2007-2011 


\section{Works Cited}

"2010 Expenditures." Open Society. N.p., n.d. Web. 19 Sept. 2012. $<$ c14989882.r82.cf2.rackcdn.com/pdfs/osf-expenditures-2010.pdf>.

"About Us | Open Society Foundations (OSF)." Open Society Foundations (OSF). http://www.opensocietyfoundations.org/about (accessed January 17, 2013).

"About the National Endowment for Democracy." National Endowment for Democracy. http://www.ned.org/about (accessed January 17, 2013).

Anable, David. "The Role of Georgia's Media and Western Aid in the Rose Revolution." The Harvard International Journal of Press/Politics 11, no. 3 (2006): 7 - 43. http:/hij.sagepub.com/content/11/3/7.full.pdf + html (accessed January 14, 2013).

Beissinger, Mark R.. "Structure and Example in Modular Political Phenomena: The Diffusion of Bulldozer/Rose/Orange/Tulip Revolutions." Perspectives on Politics 5, no. 2 (2007): 259 - 276. http://www.jstor.org/stable/20446423 (accessed January 18, 2013).

"Belarus - Country Strategy Paper 2007-2013." European Neighborhood and Partnership Instrument (2006). ec.europa.eu/world/enp/pdf/country/enpi_csp_nip_belarus_en.pdf (accessed February 13, 2013).

Bunce, Valerie J., and Sharon L. Wolchik. "Favorable Conditions and Electoral Revolutions." Journal of Democracy 17, no. 4 (2006): 5-18.

Carothers, Thomas. "The Backlash against Democracy Promotion." Foreign Affairs 85, no. 2 (2006): 55-68. Print.

D'Anieri, Paul J.. Orange Revolution and Aftermath: Mobilization, Apathy, and the State in Ukraine. Washington, D.C. Woodrow Wilson Center Press, 2010.

Degutis, Algirdas. "About Us." IISEPS, An Independent Institute of Socio-Economic and Politycal Studies. http://www.iiseps.org/eabout.html (accessed February 15, 2013).

"Development and Cooperation - EuropeAid." European Commission. ec.europa.eu/europeaid/what/human-rights/index_en.htm (accessed January 4, 2013).

Dyczok, Marta. "Was Kuchma's Censorship Effective? Mass Media in Ukraine before 2004." Europe-Asia Studies 58, no. 2 (2006): 215 - 238. http://www.jstor.org/stable/20451184 (accessed January 2, 2013).

Fairbanks, Charles. "Georgia's Rose Revolution." Journal of Democracy 15, no. 2 (2004): 110124.

Finkel, Evgeny, and Yitzhak Brundy. "No More Colour! Authoritarian Regimes and Colour 
Revolutions in Eurasia." Democratization 19, no. 1 (2012): 1-14. Print.

"FY 1995 U.S. Assistance to the NIS." U.S. Department of State.

dosfan.lib.uic.edu/ERC/bureaus/eur/nis/1995nisannual.html (accessed January 30, 2013).

"FY 1996 U.S. Assistance to Eurasia." U.S. Department of State.

www.state.gov/documents/organization/2377.pdf (accessed January 30, 2013).

"FY 1997 U.S. Assistance to Eurasia." U.S. Department of State.

pdf.usaid.gov/pdf_docs/PDABQ678.pdf (accessed January 30, 2013).

"FY 1998 U.S. Assistance to Eurasia." U.S. Department of State. www.bits.de/NRANEU/US.../US\%20Assis\%20to\%20NIS\%20Pol.htm (accessed January 30, 2013).

"FY 1999 U.S. Assistance to Eurasia." U.S. Department of State. www.fpa.org/usr_doc/37318.pdf (accessed January 30, 2013).

"FY 2000 U.S. Assistance to the NIS." U.S. Department of State. http://www.state.gov/p/eur/rls/rpt/nisasst/index.htm (accessed January 30, 2013).

"FY 2001 U.S. Assistance to Eurasia." U.S. Department of State. http://www.state.gov/p/eur/rls/rpt/c8491.htm (accessed January 30, 2013).

"FY 2002 U.S. Assistance to Eurasia." U.S. Department of State. http://www.state.gov/p/eur/rls/rpt/c10251.htm (accessed January 30, 2013).

"FY 2003 U.S. Assistance to Eurasia." U.S. Department of State. http://www.state.gov/p/eur/rls/rpt/c13148.htm (accessed January 30, 2013).

"FY 2004 U.S. Assistance to Eurasia." U.S. Department of State. http://www.state.gov/p/eur/rls/rpt/c16112.htm (accessed January 30, 2013).

"FY 2005 U.S. Assistance to Eurasia." U.S. Department of State. http://www.state.gov/p/eur/rls/rpt/c17328.htm (accessed January 30, 2013).

"FY 2006 U.S. Government Assistance to and Cooperative Activities with Eurasia." U.S. Department of State. http://www.state.gov/p/eur/rls/rpt/c23963.htm (accessed January 30, 2013).

"FY 2007 U.S. Government Assistance to and Cooperative Activities with Eurasia." U.S. Department of State. http://www.state.gov/p/eur/rls/rpt/eurasiafy07/index.htm (accessed January 30, 2013). 
"FY 2008 U.S. Government Assistance to and Cooperative Activities with Eurasia." U.S. Department of State. http://www.state.gov/p/eur/rls/rpt/eurasiafy08/index.htm (accessed January 30, 2013).

"FY 2009 U.S. Government Assistance to and Cooperative Activities with Eurasia." U.S. Department of State. http://www.state.gov/p/eur/rls/rpt/eurasiafy09/index.htm (accessed January 30, 2013).

"FY 2010 U.S. Government Assistance to and Cooperative Activities with Eurasia." U.S. Department of State. http://www.state.gov/p/eur/rls/rpt/eurasiafy10/index.htm (accessed January 30, 2013).

"Georgians party as president steps down - Nov. 23, 2003." CNN.com.

http://www.cnn.com/2003/WORLD/europe/11/23/georgia.protests/index.html (accessed February 3, 2013).

Goltz, Thomas. Georgia Diary: a Chronicle of War and Political Chaos in the Post-Soviet Caucasus. Armonk, N.Y.: Sharpe, 2006.

Horvath, Robert. "Putin's 'Preventive Counter-Revolution': Post-Soviet Authoritarianism and the Spectre of Velvet Revolution." Europe-Asia Studies 63, no. 1 (2011): 1 - 25.

Kalinovski Square. Film. Directed by Yury Khashchavatski. United States: Garden Thieves Pictures, 2009.

Karatnycky, Adrian. "Ukraine's Orange Revolution." Foreign Affairs 84, no. 2 (2005): 35 - 52. http://www.jstor.org/stable/20034274 (accessed January 2, 2013).

Keck, Margaret E., and Kathryn Sikkink. Activists Beyond Borders: Advocacy Networks in International Politics. Ithica: Cornell University Press, 1998.

Keck, Margaret E., and Kathryn Sikkink. "Transnational advocacy networks in international and regional politics." International Social Science Journal 51, no. 159 (1999): 89 - 101.

Linz, Juan J., and Alfred Stepan. "Toward Consolidated Democracies." Journal of Democracy 7 , no. 2 (1996): 14 - 33.

Marples, David R.. "Color revolutions: The Belarus case." Communist and Post-Communist Studies 39 (2006): 351 - 364.

McFaul, Michael. "Transitions from Postcommunism." Journal of Democracy 16, no. 3 (2005): 5-19.

McFaul, Michael. "Ukraine Imports Democracy." International Security 32, no. 2 (2007): 45-83. Print.

Memorial Human Rights Group. "О границах сотрудничества. Заявление «Московского 
Мемориала»." Мемориал Правозащита. www.memo.ru/d/3148.html (accessed March 28, 2012).

Miller, Judith. "Belarus Fines Soros Foundation \$3 Million in Apparent Crackdown." The New York Times, May 2, 1997. http://www.nytimes.com/1997/05/02/world/belarus-finessoros-foundation-3-million-in-apparent-crackdown.html (accessed February 13, 2013).

"Mission Statement of the U.S. Department of State and USAID." U.S. Department of State. http://www.state.gov/s/d/rm/rls/dosstrat/2004/23503.htm (accessed January 3, 2013).

"NDI Statement on the Crisis Surrounding Georgia's Parliamentary Elections. November 19, 2003." National Democratic Institute. www.ndi.org/files/1656_ge_parlelectst_111903.pdf (accessed January 14, 2013).

"NDI Annual Report." National Democratic Institute (2005). www.ndi.org/files/2219_ndi_annual_report_120105.pdf (accessed January 2, 2013).

Osborn, Andrew. "Dissidents of the theatre in Belarus pin their hopes on the denim revolution." The Independent (London), March 9, 2006. http://www.independent.co.uk/news/world/europe/dissidents-of-the-theatre-in-belaruspin-their-hopes-on-denim-revolution-469170.html (accessed February 8, 2013).

Radia, Kirit. "Russians Protest Putin in 'Big White Circle' - ABC News." ABCNews.com. http://abcnews.go.com/blogs/headlines/2012/02/russians-protest-putin-in-big-whitecircle/ (accessed February 21, 2013).

Ragin, Charles C.. The Comparative Method: Moving Beyond Qualitative and Quantitative Strategies. Berkeley: University of California Press, 1987.

"Russia." National Endowment for Democracy. http://www.ned.org/node/233 (accessed February 21, 2013).

"Russia - NGO Law Monitor." The International Center for Not-for-Profit Law (ICNL). http://www.icnl.org/research/monitor/russia.html (accessed February 21, 2013).

"Russia Votes." Centre for the Study of Public Policy - University of Strathclyde. http://www.russiavotes.org/duma/duma_vote_trends.php\#008 (accessed March 11, 2013).

"Section X." The Criminal Code Of The Russian Federation. http://www.russian-criminalcode.com/PartII/SectionX/Chapter29.html (accessed February 21, 2013).

Sector, Charlotte. "Belarusians Wear Jeans in Silent Protest." ABCNews.com. http://abcnews.go.com/International/story?id=1502762 (accessed February 16, 2013). 
Silitski, Vitali. "Belarus: Learning From Defeat." Journal of Democracy 17, no. 4 (2006): 138 152. http://muse.jhu.edu/journals/jod/summary/v017/17.4silitski.html (accessed February 11, 2013).

Specter, Michael. "Belarus Voters Back Populist in Protest at the Quality of Life." The New York Times, June 25, 1994. http://www.nytimes.com/1994/06/25/world/belarus-voters-backpopulist-in-protest-at-the-quality-of-life.html. (accessed February 13, 2013).

"State of emergency in Georgia." CNN.com.

http://www.cnn.com/2003/WORLD/europe/11/22/georgia.protests/index.html (accessed February 3, 2013).

"Ukraine GDP Data \& Country Report | Global Finance." Global Finance. http://www.gfmag.com/gdp-data-country-reports/154-ukraine-gdp-countryreport.html\#axzz1eXkvtX9o (accessed February 10, 2013).

Welt, Cory. "Causes of the Rose Revolution: Lessons for Democracy Assistance." USAID Russia and Eurasia Program 1 (2005): 1 - 12. csis.org/files/media/csis/pubs

Welt, Cory. "Georgia's Rose Revolution: From Regime Weakness to Regime Collapse." Center for Strategic and International Studies 1 (2006): 1 - 47.

www18.georgetown.edu/data/people/cdw33/publication-32608.pdf (accessed January 13, 2013).

"What we do." Organization for Security and Co-operation in Europe | OSCE. http://www.osce.org/what (accessed January 17, 2013).

Wilson, Andrew. Ukraine's Orange Revolution. New Haven: Yale University Press, 2005.

Wilson, Andrew. "Ukraine's Orange Revolution, NGOs and the Role of the West." Cambridge Review of International Affairs 19, no. 1 (2006): 21 - 32.

Wolchik, Sharon L.. "Putinism Under Siege: Can There Be a Color Revolution?." Journal of Democracy 23, no. 3 (2012): 63 - 70.

Zarakhovich, Yuri. "Belarus: 'They Knocked My Husband Down and Dragged Him Away'." TIME, March 25, 2006. http://www.time.com/time/world/article/0,8599,1176933,00.html (accessed February 13, 2013).

BelaPAN - Belorusskoe privatnoe agentstvo novostei. "Lukashenko: Poslednie vybory my sfalsifitsirovali." Belorusskie i mirovye novosti. http://news.tut.by/politics/77777.html (accessed February 16, 2013).

Bazhanov, Boris. Vospominaniya byvshchevo sekretarya Stalina. Parizh: Tretya Bolna, 1980. http://lib.ru/MEMUARY/BAZHANOW/stalin.txt. 
"Vybory 4 marta 2011 goda | Vce soobshchehiya." GOLOS - Karta narushenii na vyborakh. www.kartanarusheniy.org/2011-12-04.

"Vybory 4 marta 2012 goda | Vce soobshchehiya." GOLOS - Karta narushenii na vyborakh. http://www.kartanarusheniy.org/2012-03-04 (accessed February 18, 2013).

"Kratkoe zayavlenie assotsiatsii «GOLOS» po itogam vyborov 4 dekabrya 2011 - Assotsiatsiya «GOLOS»." Glavnoe - Assotsiatsiya «GOLOS». http://www.golos.org/news/4535 (accessed February 21, 2013).

"Svedeniya o provodyashikhsya vyborakh i referendumakh." Centralnoi izbratelnoi comissii Rossiyskoi Federatsii. http://www.vybory.izbirkom.ru/region/region/izbirkom?action=show\&root=1\&tvd=1001 $00028713304 \& v r n=100100028713299 \AA$ ion $=0 \& \mathrm{global}=1 \&$ sub_region $=0 \&$ prver $=0 \&$ pron etvd=null\&vibid=100100028713304\&type=233 (accessed February 19, 2013).

"Svedeniya o provodyashikhsya vyborakh i referendumakh." Centralnoi izbratelnoi comissii Rossiyskoi Federatsii.

http://www.vybory.izbirkom.ru/region/region/izbirkom?action=show\&root=1\&tvd=1001 $00031793509 \& \mathrm{vrn}=100100031793505 \AA$ ion $=0 \& \mathrm{global}=1 \&$ sub_region $=0 \&$ prver $=0 \&$ pron etvd=null\&vibid=100100031793509\&type=226 (accessed February 21, 2013).

\section{$\underline{\text { Additional Works Consulted }}$}

Barry, Ellen, and Michael Schwirtz. "Arrests and Violence at Overflowing Rally in Moscow." The New York Times, May 6, 2012. http://www.nytimes.com/2012/05/07/world/europe/at-moscow-rally-arrests-andviolence.html?_r=0 (accessed February 20, 2013).

Beissinger, Mark R.. "An Interrelated Wave." Journal of Democracy 20, no. 1 (2009): 74 - 77.

"Belarus - 2005 Grants." National Endowment for Democracy. http://www.ned.org/publications/annual-reports/2005-annual-report/eurasia/descriptionof-2005-grants/belarus (accessed February 15, 2013).

"Belarus - 2006 Grants." National Endowment for Democracy. http://www.ned.org/publications/annual-reports/2006-annual-report/eurasia/descriptionof-2006-grants/belarus (accessed February 15, 2013).

"Belarus GDP Data \& Country Report." Global Finance. http://www.gfmag.com/gdp-datacountry-reports/319-belarus-gdp-country-report.html\#axzz2KwYfZAoE (accessed February 15, 2013).

Bunce, Valerie J.. "Rethinking Recent Democratization." World Politics 55 (2003): 167-192. Print. 
Bunce, Valerie J., and Sharon L. Wolchik. "Getting Real About "Real Causes"." Journal of Democracy 20, no. 1 (2009): 69-73.

Church, Rosemary. "Shevardnadze rues broken promises." CNN.com. http://www.cnn.com/2003/WORLD/europe/11/23/georgia.background/index.html (accessed February 3, 2013).

Dimitrov, Martin K.. "Popular Autocrats." Journal of Democracy 20, no. 1 (2009): 78-81.

"Freedom House World Report." Freedom House. http://www.freedomhouse.org/ (accessed January 13, 2013).

"Georgia | National Endowment for Democracy." Home Page | National Endowment for Democracy. N.p., n.d. Web. 3 Oct. 2012. <http://www.ned.org/where-wework/eurasia/georgia>.

McCormack, Scott. "Belarus Harassment of NGO Partnership." U.S. Department of State. http://2001-2009.state.gov/r/pa/prs/ps/2005/55945.htm (accessed February 15, 2013).

McFaul, Michael. "Democracy promotion as a world value." The Washington Quarterly 28, no. 1 (2010): 147 - 163. http://dx.doi.org/10.1162/0163660042518189 (accessed January 2, 2013).

Miller, Judith. "Soros Closes Foundation In Belarus." The New York Times, September 4, 1997. http://www.nytimes.com/1997/09/04/world/soros-closes-foundation-in-belarus.html (accessed February 14, 2013).

Nikolayenko, Olena. "The Revolt of the Post-Soviet Generation: Youth Movement in Serbia, Georgia, and Ukraine." Comparative Politics 39, no. 2 (2007): 169 - 188.

http://www.jstor.org/stable/20434032 (accessed January 2, 2013).

Peterson, Scott. "US spends millions to bolster Belarus opposition / The Christian Science Monitor - CSMonitor.com." The Christian Science Monitor. http://www.csmonitor.com/2001/0910/p7s1-woeu.html (accessed February 15, 2013).

Polese, Abel, and Donnacha O Beachain. "The Color Revolutions Virus and Authoritarian Antidotes." Demokratizatsiya 19.2 (2011): 111-132. Print.

Sundstrom, Lisa McIntosh. "Foreign Assistance, International Norms, and NGO Development: Lessons from the Russian Campaign." International Organization 59.2 (2005): 419-449. Print.

Trenin, Dmitri, Maria Lipman, Alexey Malashenko, Sergei Aleksashenko, Natalia Bubnova, and Nikolay Petrov. "Duma Elections: Expert Analysis." Carnegie Endowment for International Peace. http://carnegieendowment.org/2011/12/13/duma-elections-expert- 
analysis/8kkf (accessed February 11, 2013).

"USAID." Fiscal Year 2011 Financial Report. N.p., n.d. Web. 24 Sept. 2012. $<$ transition.usaid.gov/performance/afr/afr11.pdf?111811>.

Way, Lucan. "A Reply to my Critics." Journal of Democracy 20, no. 1 (2009): 90 - 97.

Way, Lucan. "The Real Causes of the Color Revolutions." Journal of Democracy 19, no. 3 (2008): 55-69.

Ziegler, Charles E.. "Civil Society, political stability, and state power in Central Asia: cooperation and contestation." Democratization 17, no. 5 (3020): 795 - 825. http://dx.doi.org/10.1080/13510347.2010.501172 (accessed January 2, 2013). 